\title{
The Pathophysiological Role of CoA
}

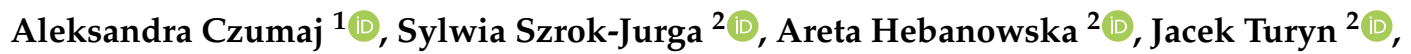 \\ Julian Swierczynski ${ }^{3}$, Tomasz Sledzinski ${ }^{1, *(\mathbb{D})}$ and Ewa Stelmanska ${ }^{2, * \mathbb{D}}$ \\ 1 Department of Pharmaceutical Biochemistry, Faculty of Pharmacy, Medical University of Gdansk, \\ 80-211 Gdańsk, Poland; Aleksandra.czumaj@gumed.edu.pl \\ 2 Department of Biochemistry, Faculty of Medicine, Medical University of Gdansk, 80-211 Gdansk, Poland; \\ szrok@gumed.edu.pl (S.S.-J.); areta.hebanowska@gumed.edu.pl (A.H.); jacek.turyn@gumed.edu.pl (J.T.) \\ 3 State School of Higher Vocational Education in Koszalin, 75-582 Koszalin, Poland; juls@gumed.edu.pl \\ * Correspondence: tomasz.sledzinski@gumed.edu.pl (T.S.); ewa.stelmanska@gumed.edu.pl (E.S.); \\ Tel.: +48-(0)-583-491-479 (T.S.)
}

Received: 16 October 2020; Accepted: 25 November 2020; Published: 28 November 2020

\begin{abstract}
The importance of coenzyme A ( $\mathrm{CoA})$ as a carrier of acyl residues in cell metabolism is well understood. Coenzyme A participates in more than 100 different catabolic and anabolic reactions, including those involved in the metabolism of lipids, carbohydrates, proteins, ethanol, bile acids, and xenobiotics. However, much less is known about the importance of the concentration of this cofactor in various cell compartments and the role of altered CoA concentration in various pathologies. Despite continuous research on these issues, the molecular mechanisms in the regulation of the intracellular level of CoA under pathological conditions are still not well understood. This review summarizes the current knowledge of (a) CoA subcellular concentrations; (b) the roles of CoA synthesis and degradation processes; and (c) protein modification by reversible CoA binding to proteins (CoAlation). Particular attention is paid to (a) the roles of changes in the level of CoA under pathological conditions, such as in neurodegenerative diseases, cancer, myopathies, and infectious diseases; and (b) the beneficial effect of CoA and pantethine (which like CoA is finally converted to Pan and cysteamine), used at pharmacological doses for the treatment of hyperlipidemia.
\end{abstract}

Keywords: CoA; coenzyme A; CoAlation; cancer; neurodegenerative diseases

\section{Introduction}

Coenzyme A (CoA or $\mathrm{CoA}-\mathrm{SH})$ is an essential cofactor of cellular metabolism in all living organisms. Pantothenic acid (Pan, commonly known as vitamin B5) is the only nutritionally essential component involved in the synthesis of $\mathrm{CoA}$, which is required for many biochemical processes (see below) and for the synthesis of an acyl carrier protein that is involved in fatty acid biosynthesis [1,2]. Moreover, Pan triggers immune cells to produce cytokines [3].

The name of Pan is derived from the root word pantos, which means "everywhere." The widespread availability of Pan in the diet (both in products of animal, including milk, and plant origin) means that, in humans, Pan deficiency occurs largely due to severe malnutrition with combined vitamin deficiencies. However, it was recently found that cerebral Pan levels are significantly decreased compared to the control values in patients with Huntington's disease [4]. Moreover, Pan deficiency results in greying hair in rats and other animals. Studies have shown that vitamin $\mathrm{B}_{5}$ supplementation with calcium pantothenate can promote grey hair darkening [5]. Neither the toxicity nor the upper intake level have been established [6]. However, in some individuals consuming very large doses of Pan supplements (approximately $10 \mathrm{~g}$ per day), gastrointestinal distress and diarrhea have been observed [2]. 
The unique chemical structure of CoA-SH allows it to be used to activate carboxylic acids involved in both catabolic and anabolic reactions. Generally, in humans, CoA-SH is required for (a) chemical reactions that generate energy from fat, carbohydrates, protein and catabolism of ethanol; (b) biosynthesis of fatty acids (necessary for biosynthesis of: triacylglycerols, phospholipids, sphingolipids), cholesterol, acetylcholine, prenyl moieties, bile acids, ketone bodies, heme, melatonin, glycosaminoglycans, glycoproteins, gangliosides, proteoglycans, and others) [7,8]; (c) regulation of metabolism (direct allosteric regulation of pyruvate dehydrogenase kinase-PDK, carnitine palmitoyltransferase $1-\mathrm{CPT} 1$ and indirect regulation of carbamoyl phosphate syntethase I); and (d) gene expression (e.g., histone acetylation) [9]. Moreover, $\mathrm{CoA}-\mathrm{SH}$ and its thioester derivatives (mainly acetyl-CoA and benzoyl-CoA) participate in detoxification reactions during which compounds are formed and then excreted in urine, e.g., hippuric or mercapturic acids [10]. The recently discovered, unconventional function of free $\mathrm{CoA}(\mathrm{CoA}-\mathrm{SH})$ is protein CoAlation. This process is related to redox regulation and antioxidant defense [11]. Exemplary reactions that involve CoA-SH as a substrate and reactions in which CoA-SH is released as a product in human cells are presented in Tables 1 and 2.

The major pools of CoA-SH and its thioesters are found in mitochondria and the cytosol. Other organelles (peroxisome, nuclei, lysosomes, and endoplasmic reticulum) contain much less CoA-SH. In mitochondria, CoA-SH is used in: (a) fatty acids and ketone bodies oxidation (as a substrate for thiolases and carnitine palmitoyltransferase 2-CPT2); (b) tricarboxylic acid cycle (as a substrate for $\alpha$-oxoglutarate dehydrogenase); and (c) oxidative decarboxylation of pyruvate and branched-chain $\alpha$-keto acids [12]. In the cytosol, CoA-SH is mainly used in reactions catalyzed by ATP-citrate lyase (ACLY) and acyl-CoA synthetase (ACS) (Table 1).

Table 1. Examples of reactions with the participation of CoA-SH as a substrate in human cells; based on Ridgway and Mcleod and the UniProt database [7,13].

\begin{tabular}{|c|c|c|c|}
\hline \multicolumn{4}{|c|}{ CoA-SH as a Substrate } \\
\hline & Enzyme & Reaction & Process \\
\hline \multirow{3}{*}{ Lipid metabolism } & acyl-CoA synthetases (ACS) & $\begin{array}{c}\text { fatty acid }+ \text { CoA-SH }+\mathrm{ATP} \rightarrow \\
\text { fatty acyl-CoA }+\mathrm{AMP}+\mathrm{PP}_{\mathrm{i}}\end{array}$ & fatty acids activation \\
\hline & $\begin{array}{c}\text { carnitine } \\
\text { palmitoyltransferase } 2 \\
\text { (CPT2) }\end{array}$ & $\begin{array}{c}\text { acylcarnitine }+\mathrm{CoA}-\mathrm{SH} \rightarrow \\
\text { carnitine }+ \text { fatty acyl-CoA }\end{array}$ & carnitine shuttle \\
\hline & ATP-citrate lyase (ACLY) & $\begin{array}{c}\text { citrate }+ \text { ATP }+ \text { CoA-SH } \rightarrow \text { oxaloacetate }+ \\
\text { acetyl-CoA }+ \text { ADP }+\mathrm{P}_{\mathrm{i}}\end{array}$ & $\begin{array}{l}\text { lipogenesis, synthesis of } \\
\text { cholesterol and others }\end{array}$ \\
\hline \multirow{2}{*}{$\begin{array}{l}\text { Lipid, carbohydrate, } \\
\text { amino acids and } \\
\text { ethanol metabolism }\end{array}$} & $\begin{array}{c}\alpha \text {-oxoglutarate } \\
\text { dehydrogenase complex }\end{array}$ & $\begin{array}{c}\alpha \text {-oxoglutarate }+\mathrm{CoA}-\mathrm{SH}+\mathrm{NAD}^{+} \rightarrow \\
\text { succinyl-CoA }+\mathrm{NADH}+\mathrm{H}^{+}+\mathrm{CO}_{2}\end{array}$ & tricarboxylic acid cycle \\
\hline & acetyl-CoA synthetase & $\begin{array}{c}\text { acetate }+ \text { CoA-SH }+ \text { ATP } \rightarrow \text { acetyl-CoA } \\
+\mathrm{AMP}+\mathrm{PP}_{\mathrm{i}}\end{array}$ & $\begin{array}{l}\text { ethanol metabolism, } \\
\text { acetate formed by gut } \\
\text { microbiota metabolism }\end{array}$ \\
\hline
\end{tabular}


Table 2. Examples of reactions involving CoA-SH as a product in human cells; based on Ridgway and Mcleod and the UniProt database [7,13].

\begin{tabular}{|c|c|c|c|}
\hline \multicolumn{4}{|c|}{ CoA-SH as a Product } \\
\hline & Enzyme & Reaction & Process \\
\hline \multirow{6}{*}{ Lipid metabolism } & fatty acid synthase (FASN) & $\begin{array}{c}7 \text { malonyl-CoA }+ \text { acetyl-CoA }+14 \\
\mathrm{NADPH}+14 \mathrm{H}^{+} \rightarrow \text { palmitate }+14 \\
\mathrm{NADP}^{+}+7 \mathrm{CO}_{2}+6 \mathrm{H}_{2} \mathrm{O}+ \\
\mathbf{8} \mathbf{C o A}-\mathrm{SH}\end{array}$ & lipogenesis \\
\hline & fatty acid elongases (ELOVLs) & $\begin{array}{c}\text { fatty acyl-CoA }+ \text { malonyl-CoA } \rightarrow \\
\beta \text {-keto-acyl-CoA }+\mathrm{CO}_{2}+\mathrm{CoA}-\mathrm{SH} \\
\text { or } \\
\text { fatty acyl-CoA + acetyl-CoA } \rightarrow \\
\beta \text {-keto-acyl-CoA }+ \text { CoA-SH }\end{array}$ & $\begin{array}{l}\text { microsomal elongation of } \\
\text { fatty acid chains } \\
\text { mitochondrial elongation of } \\
\text { fatty acid chains }\end{array}$ \\
\hline & $\begin{array}{c}\text { acyltransferases } \\
\text { e.g., diacylglycerol } \\
\text { O-acyltransferase (DGAT) } \\
\text { e.g., acyl-CoA:cholesterol } \\
\text { acyltransferase (ACAT) }\end{array}$ & $\begin{array}{c}\text { 1,2-diacylglycerol + fatty acyl-CoA } \\
\rightarrow \text { triacylglycerol + CoA-SH } \\
\text { cholesterol + acyl-CoA } \rightarrow \\
\text { cholesteryl ester + CoA-SH }\end{array}$ & $\begin{array}{l}\text { triacylglycerol synthesis } \\
\text { cholesterol metabolism }\end{array}$ \\
\hline & $\begin{array}{c}\text { carnitine palmitoyltransferase } 1 \\
\text { (CPT1) }\end{array}$ & $\begin{array}{l}\text { carnitine }+ \text { acyl-CoA } \rightarrow \\
\text { acylcarnitine }+ \text { CoA-SH }\end{array}$ & carnitine shuttle \\
\hline & $\begin{array}{l}\text { 3-hydroxy-3-methylglutaryl-CoA } \\
\text { reductase (HMGR) }\end{array}$ & $\begin{array}{l}\mathrm{HMG}-\mathrm{CoA}+2 \mathrm{NADPH}+2 \mathrm{H}^{+} \rightarrow \\
\text { mevalonate }+2 \mathrm{NADP}^{+}+\mathrm{CoA}-\mathrm{SH}\end{array}$ & $\begin{array}{c}\text { synthesis of cholesterol, } \\
\text { cholecalciferol (skin), prenyl } \\
\text { moieties }\end{array}$ \\
\hline & acyl-CoA thioesterases & $\begin{array}{c}\text { fatty acyl-CoA }+\mathrm{H}_{2} \mathrm{O} \rightarrow \text { free fatty } \\
\text { acid }+\mathrm{CoA}-\mathrm{SH}\end{array}$ & $\begin{array}{l}\text { regulation of intracellular } \\
\text { levels of acyl-CoA, free fatty } \\
\text { acids and CoASH }\end{array}$ \\
\hline \multirow{2}{*}{$\begin{array}{l}\text { Lipid, carbohydrate, } \\
\text { amino acids and } \\
\text { ethanol metabolism }\end{array}$} & citrate synthase & $\begin{array}{c}\text { acetyl-CoA }+ \text { oxaloacetate }+\mathrm{H}_{2} \mathrm{O} \rightarrow \\
\text { citrate }+\mathrm{CoA}-\mathrm{SH}\end{array}$ & tricarboxylic acid cycle \\
\hline & $\begin{array}{c}\text { succinate thiokinase } \\
\text { (also called succinyl-CoA } \\
\text { synthetase) }\end{array}$ & $\begin{array}{l}\text { succinyl-CoA + ADP }(G D P)+P_{i} \rightarrow \\
\text { succinate + ATP }(G T P)+\text { CoA-SH }\end{array}$ & tricarboxylic acid cycle \\
\hline Others & $\begin{array}{c}\text { acetyltransferases } \\
\text { e.g., choline O-acetyltransferase } \\
\text { e.g., histone acetyltransferase } \\
\text { (HAT) }\end{array}$ & $\begin{array}{c}\text { choline + acetyl-CoA } \rightarrow \\
\text { acetylcholine + CoA-SH } \\
\text { histone-Lys + acetyl-CoA } \rightarrow \\
\text { histone-Lys-acetyl + CoA-SH }\end{array}$ & $\begin{array}{l}\text { neurotransmitters synthesis } \\
\text { protein acetylation }\end{array}$ \\
\hline
\end{tabular}

The acyl groups formed during the metabolism of glucose, amino acids and fatty acids in human cells and those produced by gut microbiota are attached to $\mathrm{CoA}-\mathrm{SH}$ to form its thioester derivatives, such as acetyl-CoA, succinyl-CoA, propionyl-CoA, isovaleryl-CoA, isobutyryl-CoA, $\alpha$-methylbutyryl-CoA, and fatty acyl-CoA (commonly referred to as acyl-CoA), e.g., palmitoyl-, oleoyl-, and stearoyl-CoA (Figure 1A).

Itaconyl-CoA, a derivative of a newly discovered mammalian metabolite, itaconate, inhibits B12dependent methylmalonyl-CoA mutase [14].

Among the abovementioned compounds, acetyl-CoA is the central and most important metabolite and forms an intersection between the anabolic and catabolic pathways [15]. Moreover, other important metabolites, such as malonyl-CoA (a substrate of lipogenesis and regulator of fatty acid oxidation) and 3-hydroxy-3-methylglutaryl-CoA (HMG-CoA) (a substrate for cholesterol and ketone bodies synthesis), are formed from acetyl-CoA (Figure 1B) [15,16].

The pool of CoA-SH in the cell is replenished by the enzymes that release it from thioester compounds, e.g., citrate synthase, acyl-coenzyme A: cholesterol acyltransferase (ACAT), many acyland acetyltransferases, acyl-CoA thioesterases, fatty acid synthase (FASN), fatty acid elongase (ELOVL), 3-hydroxy-3-methylglutaryl-CoA reductase (HMGR), and CPT1 (Table 2), [17-21].Notably, changes in the $\mathrm{CoA}-\mathrm{SH} /$ acetyl-CoA ratio affect not only the regulation of energy metabolism but also the regulation of other cellular processes, such as autophagy, mitosis, and cell death [20,22]. 
(A)

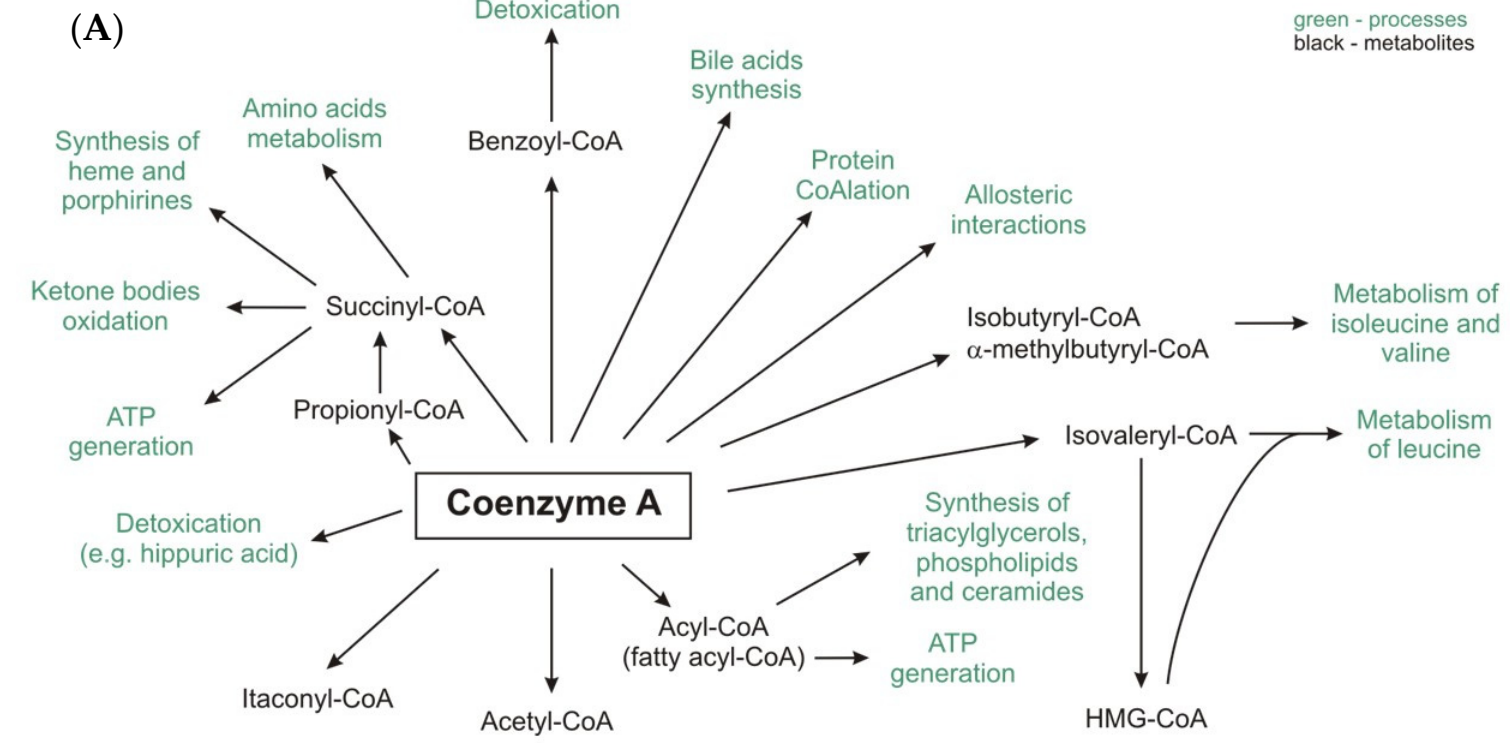

(B)

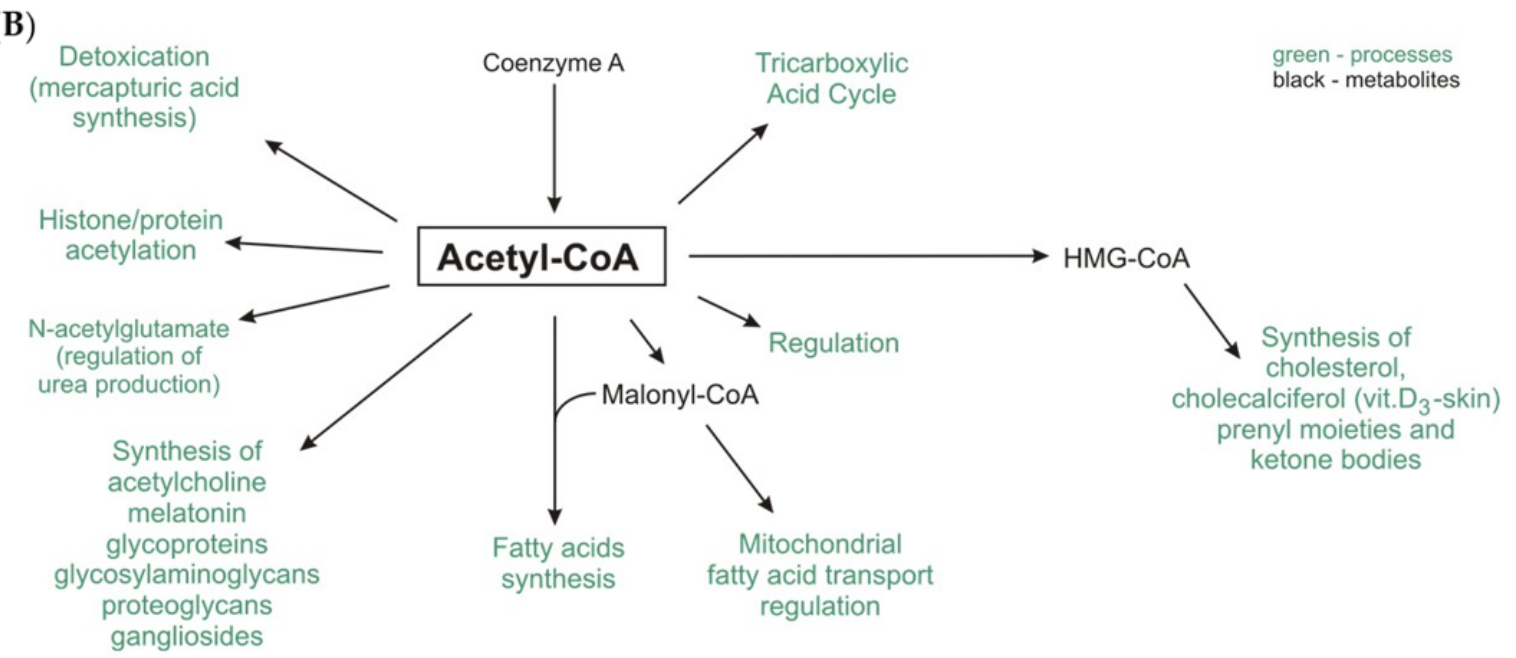

Figure 1. The role of CoA-SH (A) and acetyl-CoA (B) in human metabolism.

This review summarizes current knowledge of CoA-SH subcellular concentrations, the roles of $\mathrm{CoA}-\mathrm{SH}$ synthesis and degradation processes and changes in the level of CoA-SH under pathological conditions, such as neurodegenerative diseases, cancer, myopathies, infectious diseases and the genetic make-up of CoA-SH genes. Finally, the beneficial effects of CoA-SH and pantethine (a dimer of the CoA precursor pantetheine) used at pharmacological doses for the treatment of hyperlipidemia are presented.

\section{CoA Synthesis and Degradation in Mammalian Cells}

\subsection{CoA Synthesis}

The substrates for CoA-SH biosynthesis are Pan, cysteine and ATP. There are three main sources of blood-circulating Pan: (a) food; (b) gut microbiota; and (c) extracellular products of CoA-SH degradation of damaged cells and recycled cellular content (exocytosis) [23-26]. In the diet, CoA-SH is the main source of Pan (approx. 85\% of dietary Pan is in the form of CoA-SH or phosphopantetheine), which is hydrolyzed in the intestine, and Pan, which is thus formed, is then absorbed [26-28]. In mammals, Pan is absorbed in the intestine and transported into cells through sodium-dependent multivitamin 
transporter (SMVT) $[23,27]$. Pan delivered into the bloodstream is transported throughout the body (to organs) by red blood cells [29].

The first step of CoA-SH biosynthesis is the phosphorylation of intercellular Pan to $4^{\prime}$-phosphopantothenate (PPan) by pantothenate kinase (PANK). Then PPan is condensed with cysteine by phosphopantothenoylcysteine synthetase (PPCS), followed by decarboxylation by phosphopantothenoylcysteine decarboxylase (PPCDC) to generate $4^{\prime}$-phosphopantetheine (PPanSH) [30]. Human PPCS utilizes ATP to activate substrate in a ligation reaction. An acyl adenylate intermediate is formed, followed by release of pyrophosphate, and binding of cysteine, and then, the final products, $4^{\prime}$-phosphopantothenoylcysteine and AMP, are formed [31]. In mammals, in contrast to other organisms, the last two steps in the CoA-SH biosynthetic pathway are catalysed by CoA synthase (COASY), which exhibits two enzymatic activities: 4'-phosphopantetheine adenyltransferase (PPAT) and a dephospho-CoA kinase (DPCK) [30]. PPanSH is first converted to dephospho-CoA (dPCoA) and subsequently phosphorylated to form CoA-SH. The CoA-SH synthesis pathway is presented in Figure 2.

Regulation of CoA-SH synthesis takes place mainly at the level of the first reaction (PANK) [32]. There are four active mammalian (human) PANK isoforms involved in this process (PANK1 $\alpha$, PANK1 $\beta$, PANK2, and PANK3) encoded by three distinct genes (PANK1-3). They are localized in different subcellular compartments, which allows them to acts as local sensors of CoA levels and regulate the biosynthetic pathway [33]. Human PANK proteins share a homologous C-terminal catalytic domain, but they have different $\mathrm{N}$-termini. PANK $1 \alpha$ is exclusively localized in the nucleus, whereas PANK1 $\beta$ is localized in the cytosol and is association with clathrin-coated vesicles and recycling endosomes [34]. Human PANK2 is detected in the nucleus and mitochondria, specifically in the intermembrane space. The PANK3 isoform is exclusively localized in the cytosol [34]. The different subcellular localizations of the PANK isoforms enable these proteins to act as metabolic sensors that modulate the rate of CoA-SH synthesis to align with the cellular metabolic state. The reactions catalyzed by PANKs are rate-limiting and subjected to feedback regulation by CoA-SH or its derivatives (mainly acetyl-CoA). It is thought that PANK2 and PANK3 are not active under physiological conditions associated with high acetyl-CoA levels, especially in mitochondria [33]. The different isoforms most likely compensate for each other to maintain adequate CoA-SH levels.

COASY is a secondary regulatory site, which become important only when the flux through the pathway is dramatically increased by overexpression of PANK [32]. In mammalian cells, there is one gene for COASY and it encodes three isoforms. Activities of mammalian COASY were reported in the cytosol, the outer mitochondrial membrane and the mitochondrial matrix, and it is probably anchored to the inner mitochondrial membrane [30,35]. Mitochondrial COASY is activated by phospholipids [35]. It has been proposed that COASY may function as a scaffold protein for the formation of the CoA-SH biosynthetic complex [30]. COASY activity is regulated by the phosphorylation/dephosphorylation of tyrosine residues. This posttranslational modification affects the interactions of COASY with the SH2 domain in several signaling proteins. Fasting, glucagon, glucocorticoids, oxidative stress and treatment with hypolipidemic drugs can increase the total level of CoA-SH. On the other hand, glucose, insulin, fatty acids and pyruvate were shown to decrease the level of intracellular CoA-SH $[30,36]$.

The enzymes involved in CoA-SH synthesis and degradation are localized in various organelles (Figure 3). 


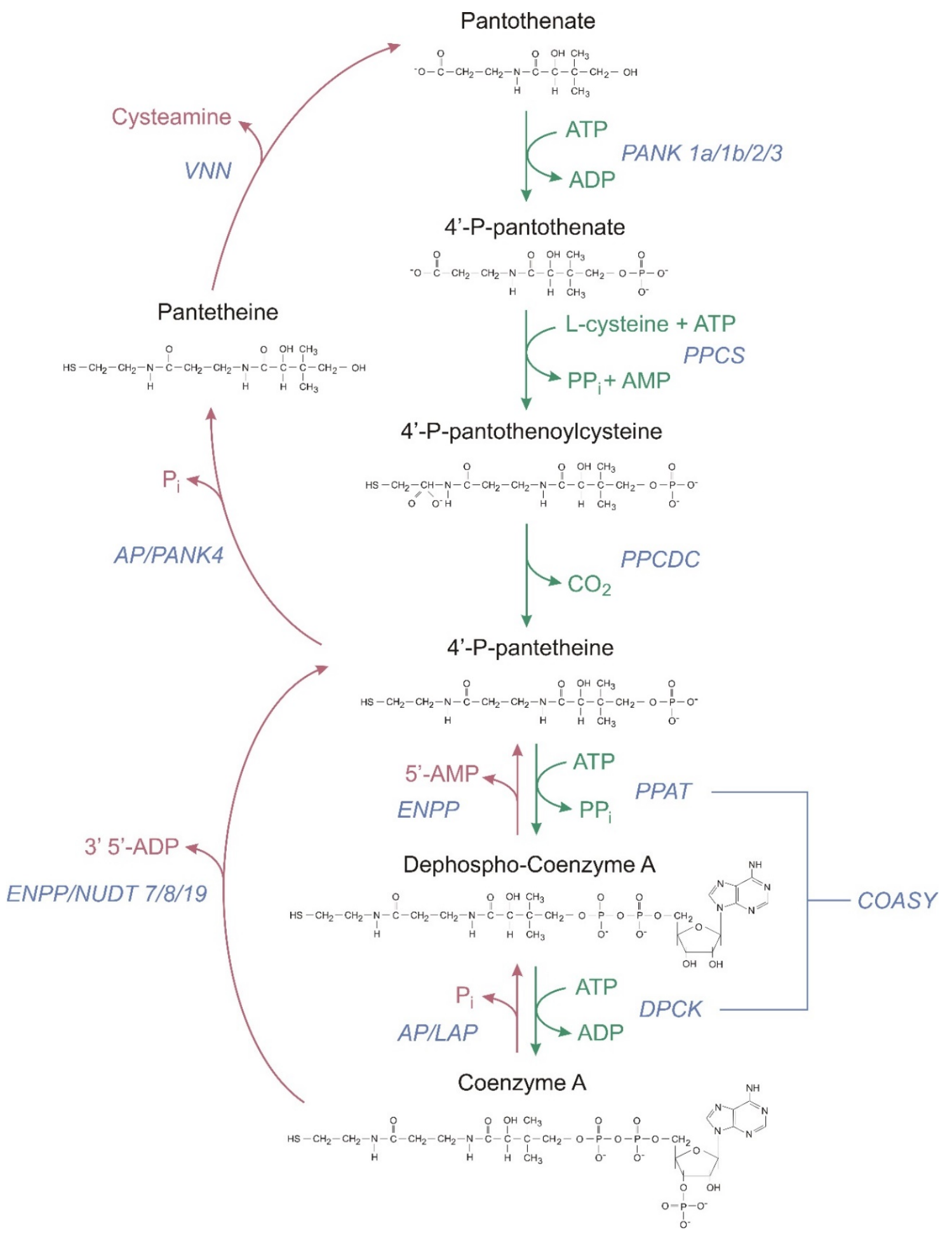

Figure 2. Coenzyme A biosynthetic and degradation pathways in humans. Green arrows indicate CoA synthesis and red arrows indicate CoA degradation. PANK-pantothenate kinase, PPanSH-4'-phosphopantetheine, PPCS-phosphopantothenoylcysteine synthetase, PPCDC - phosphopantothenoylcysteine decarboxylase, COASY —CoA synthase, PPAT-4'phosphopantetheine adenyltransferase, DPCK-dephospho-CoA kinase, ENPP-ectonucleotide pyrophosphatase/phosphodiesterase, AP-alkaline phosphatase, VNN-pantetheinase, NUDTintracellular degradation, nudix (nucleoside diphosphate linked moiety X)-type motif, and LAPlysosomal acid phosphatase. 


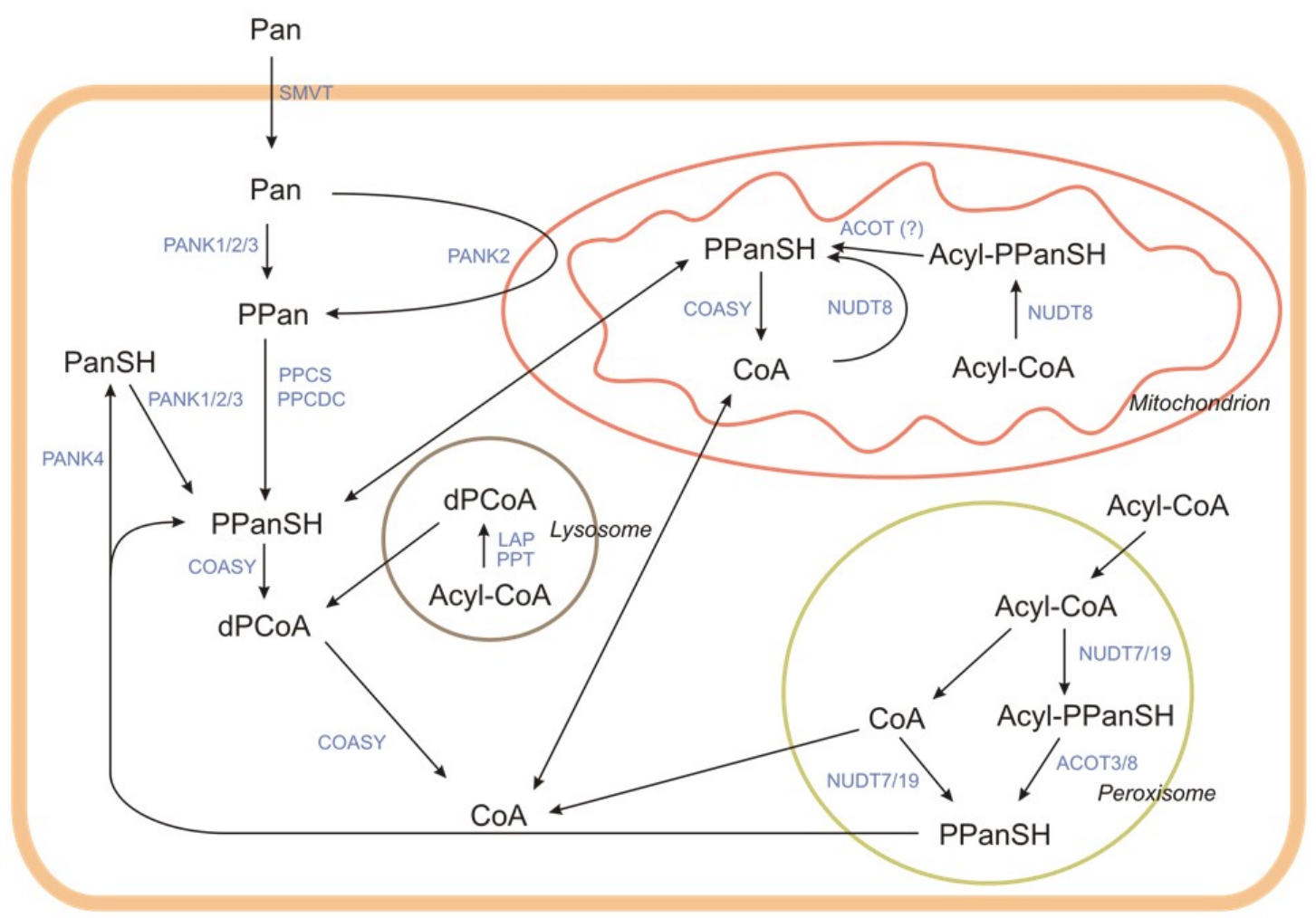

Figure 3. The compartmentalization and interplay of intracellular CoA synthesis and degradation pathways. Pan-pantothenate, PPan $-4^{\prime}$-phosphopantothenate, PPanSH-4'-phosphopantetheine, dPCoA-dephospho-CoA, PANK-pantothenate kinase, PPCS-phosphopantothenoylcysteine synthetase, PPCDC-phosphopantothenoylcysteine decarboxylase, COASY-CoA synthase, PanSH — pantetheine, NUDT—intracellular degradation, nudix (nucleoside diphosphate linked moiety X)-type motif, LAP_lysosomal acid phosphatase, SMVT—sodium-dependent multivitamin transporter, and ACOT-acyl-CoA thioesterase. The figure was made based on Naquet et al. [23].

\subsection{CoA Degradation}

Degradation of CoA-SH may be an extracellular (intestinal or systemic) or intracellular process [23]. The extent of CoA-SH degradation depends on the supply of CoA-SH in the food and physiological state of the organism, as it determines CoA-SH usage in different metabolic processes [31].

\subsubsection{Extracellular Degradation of CoA (Known as Intestinal or Systemic)}

The CoA-SH degradation pathway is presented in Figures 2 and 3. This pathway is catalyzed by the membrane or soluble enzymes, and not all of them are specific for CoA degradation. In systemic degradation they can hydrolyze not only the CoA-SH but also different types of acyl-CoA. However, it is not well known at which step of the acyl-CoA degradation process, the acyl group is removed [37]. The degradation of CoA-SH to pantetheine (PanSH) and finally to Pan, which is used as a substrate for intracellular CoA-SH synthesis, is a sequence of reactions including dephosphorylations and removal of nucleotide moiety (Figure 2). One of the first steps is the hydrolysis of diphosphate bond in CoA-SH, with the release of PPanSH, catalyzed by the alkaline ectonucleotide pyrophosphatase/phosphodiesterase (ENPP). Those are the promiscuous enzymes, which break down the $5^{\prime}$-phosphodiester bonds in nucleotides and their derivatives, may use not only the CoA-SH but also dPCoA as a substrate (dPCoA is preferred) [38,39].

In the intestinal degradation of CoA-SH the first step is most likely catalyzed by alkaline phosphatase (AP), an enzyme highly abundant in the intestinal lumen [25]. The product of this reaction, dPCoA, is later hydrolyzed by ENPP with the release of 5'-AMP and PPanSH. In systemic degradation, ENPP hydrolyzes the phosphodiester bond in CoA-SH, transforming CoA-SH into PPanSH and 
producing $3^{\prime}, 5^{\prime}$-ADP. Two ENPP isoforms (1 and 3) are probably involved in this process. Both are transmembrane glycoprotein homodimers, but some soluble forms have also been detected $[40,41]$. PPanSH released from CoA-SH or dPCoA is then dephosphorylated by AP or other unknown, phosphatases to PanSH.

The last step of the extracellular CoA-SH degradation pathway is catalyzed by a specific regulatory enzyme-pantetheinase, also known as vanin (VNN). Pantheteinase produces Pan and cysteamine from PanSH by specific cleavage of an amide bond, thus providing Pan as a precursor for intracellular CoA-SH synthesis [42]. Two isoforms (VNN1 and VNN3) are present in mice, and three isoforms are present in humans (VNN1-3) [43-45]. VNN1 is the most widely expressed GPI-anchored ectoenzyme. It is found in the membranes of epithelial cells, including ileal enterocytes and kidney proximal tubule epithelial cells. An additional soluble form secreted from hepatocytes has also been detected [46-48]. VNN3 is found in various tissues, and this isoform is not attached to membranes, and its expression is upregulated in the inflammatory state or during oxidative stress. Together VNN1 and VNN3 contribute to extracellular pantetheine degradation $[44,49]$.

\subsubsection{Intracellular Degradation of CoA}

The steps of intracellular CoA-SH degradation are similar to the extracellular process. However, there are some differences, with the greatest being in the final step, when PPanSH, and eventually PanSH, is produced. Because of the lack of VNN, Pan is not produced in the intracellular process. In the cell, CoA-SH is degraded in many organelles, such as mitochondria, peroxisomes, and lysosomes. Some steps are undertaken in the cytosol.

In the mitochondrial matrix, $\mathrm{CoA}-\mathrm{SH}$ and acyl-CoA are degraded by nudix (nucleoside diphosphate linked moiety X)-type motif (NUDT8) to PPanSH or acyl-4'-P-pantetheine, respectively, with the release of $3^{\prime}, 5^{\prime}$-ADP [50]. The family of NUDT hydrolases contains enzymes with a high affinity for acyl-CoA. Along with mitochondrial NUDT8, two other NUDT hydrolases (NUDT7 and NUDT19) participate in the intracellular CoA-SH degradation process. They differ not only in subcellular localization but also in a regulation pattern, size, and tissue distribution [50-52]. Mitochondrial NUDT8 is widely distributed among tissues. In mice, the highest amounts of NUDT8 are found in mitochondria of kidneys, heart, brown adipose tissue, liver, brain, heart, and skeletal muscles. NUDT8 hydrolyzes CoA-SH and short- and medium-chain acyl-CoA to acyl-4'-P-pantetheine [50]. The fate of the acyl-PPanSH produced in mitochondria is currently unknown. Possibly it is degraded by ACOT, but this remains speculative since there is no evidence.

Acyl-CoA degradation in peroxisomes is similar to that in the mitochondrial pathway. NUDT7 and NUDT19 are involved. NUDT7 is active against short- and medium-chain acyl-CoAs, and this activity is higher than that against CoA-SH. In mouse liver, its expression is regulated by feeding-fasting cycles, probably through PPAR $\alpha$ action [50-53]. NUDT19 in mice is found mostly in kidneys. Its main substrate is CoA-SH, but it also shows high activity against some short- and medium-chain acyl-CoAs [52,54]. As in mitochondria, the acyl-CoAs are degraded to acyl-4'-P-pantetheine. Based on unpublished experimental results, Hunt et al. suggest that the recombinant mouse ACOT3 and ACOT8 both hydrolyze lauryl-PPanSH [55]. Antonenkov and Hiltunen suggest that the removal of fatty acids from acyl-4'-P-pantetheine could allow the PPanSH to exit peroxisomes, and enter the cytosol through a specific transporter, or freely through the membrane [56]. However, there is no clear evidence shows that PPanSH, whether produced from free CoA or acyl-CoA, reaches the cytosol [23].

Lysosomal degradation of acyl-CoA is different from peroxisome and mitochondrion degradation (Figure 3). Under acidic conditions, lysosomal acidic phosphatase 2 (LAP2) removes the phosphate group from either CoA-SH or acyl-CoA, producing dephospho-acyl-CoA [57]. In contrast to other organelles, in lysosomes, long-chain acyl-CoAs are degraded. LAP2 cooperates with palmitoyl-protein thioesterase (PPT) [58-60]. This cooperation leads to the final lysosomal product, which is dPCoA. There is no evidence for the existence of a lysosomal $\mathrm{dPCoA}$ transporter, but some putative candidate proteins have been found [61]. 
Some evidence suggests that a small pool of PPanSH could be further degraded to PanSH by an unknown phosphatase. The most likely candidate seems to be pantothenate kinase 4 (PANK4), a bifunctional enzyme inactive as a kinase but with weak phosphatase activity towards PPanSH [25].

\section{Tissue Levels and Intracellular Distribution}

Total CoA levels (sum od CoA-SH and its thioesters) in various mammalian tissues span a range greater than 10-fold [36]. The total CoA level is relatively low in the cell, and CoA-SH is dynamically converted into thioesters; therefore, measuring $\mathrm{CoA}-\mathrm{SH}$ level is challenging. The recently described method of Frank et al. [62] based on HPLC with absorbance or fluorescence output detector allows the determination of the total CoA-SH concentration in a faster and easier way than other methods, and it can be used with a broad linear range of samples from cultured cells or animal tissues. The liver, a very active organ critical for many synthesis activities, and the cardiac muscle, which depends on a high rate of substrate oxidation for energy, have the highest $\mathrm{CoA}-\mathrm{SH}$ levels, followed by brown adipose tissue, kidney, brain, adrenal glands, and white skeletal muscle in rodents $[33,36,63]$.

The total CoA concentration in the livers of ad libitum fed rats ranges from 87 to $434 \mathrm{nmol} / \mathrm{g}$ tissue [64-66]. The reported values vary significantly, probably because different assay methods were used in these studies. Comparable concentration of total CoA were found in the livers of mice $120-160 \mathrm{~nm} / \mathrm{g}$ of wet tissue [33,62]. Liver total CoA levels and hepatic PanK activity are altered in response to nutritional state, insulin, glucagon, glucocorticoids, fibrate, and diabetes [67]. The rat heart contains approximately $100 \mathrm{nmol}$ total CoA/g of tissue [31]. The concentrations of $\sim 9 \mathrm{nM}$ and $\sim 0.3 \mathrm{nM}$ of plasma CoA-SH and acetyl-CoA respectively, were reported in rat [64], however, considering that CoA-SH and acetyl-CoA are rapidly degraded in circulation [24] this issue needs further studies. The levels of total CoA in rat liver and heart are presented in Table 3.

Table 3. The level of total CoA in different tissues of the rats [23,31,64-66].

\begin{tabular}{|c|c|c|c|}
\hline & Tissue & & Total CoA Concentration/Level \\
\hline \multirow{4}{*}{ Liver } & & & $87-434 \mathrm{nmol} / \mathrm{g}$ tissue \\
\hline & \multirow{3}{*}{ Subcellular compartment } & cytosol & $0.1-0.14 \mathrm{mM}$ \\
\hline & & mitochondria & $5.29 \mathrm{mM}$ \\
\hline & & peroxisomes & $0.7 \mathrm{mM}$ \\
\hline \multirow{3}{*}{ Heart } & & & $\sim 100 \mathrm{nmol} / \mathrm{g}$ tissue \\
\hline & \multirow{2}{*}{ Subcellular compartment } & cytosol & $0.014 \mathrm{mM}$ \\
\hline & & mitochondria & $2.26 \mathrm{mM}$ \\
\hline
\end{tabular}

In human hepatoma or breast adenocarcinoma where glycolysis is more intense than oxidative phosphorylation or the tricarboxylic acid cycle, the level of CoA-SH is significantly lower than it is in normal tissues. Regardless of whether the tumors are spontaneous or induced chemically, physically, or biologically, the CoA-SH level is reduced. Moreover, decreased levels of CoA-SH expressed in Lipmann Units were observed not only in cancerous tissue but also in other normal tissues of animals bearing malignant tumors [68]. In isolated hearts perfused only with Krebs-Henseleit buffer and glucose, $80 \%$ of total CoA is in the CoA-SH form, while in the presence of high concentrations of fatty acids, pyruvate, or ketone bodies, approximately $80 \%$ of CoA exists as acyl esters and acetyl-CoA [63].

The total CoA level and the CoA-SH:CoA thioester concentration ratio, together with the subcellular location of these forms, provide important parameters indicating the level of key metabolic reactions catalyzed by acyl-CoA synthetase, pyruvate dehydrogenase complex, and $\alpha$-oxoglutarate dehydrogenase [63]. Due to the presence of large nuclear pores, the cytosolic CoA-SH concentration may equilibrate with that of the nucleus [23]. The level of total cytosolic and nuclear CoA in rat heart and liver ranges from 0.014 to $0.14 \mathrm{mM}$, whereas its concentrations in mitochondria and peroxisomes 
are significantly higher, from 2.26 to greater than $5 \mathrm{mM}$ and $0.7 \mathrm{mM}$, respectively [23]. It is estimated that the pools of total CoA in heart and liver mitochondria represent approximately $95 \%$ and $80 \%$, respectively, of the total cellular CoA [23]. Therefore, in the rat liver, the cytosolic CoA-SH level is estimated to be $20 \%$, whereas in the heart, it is approximately $5 \%$. In conclusion, the predominant CoA-SH pools are in the mitochondria in both the liver and heart.

The total CoA in the liver peroxisomes ranges from 2 to $4 \%$ of the total [23,63]. Moreover, the endoplasmic reticulum lumen may also contain acetyl-CoA that can be used to acetylate proteins residing in and moving through the endoplasmic reticulum $[23,69,70]$. The percentages of the total $\mathrm{CoA}$ in these pools remain unknown, but considering the data presented above, they are very low.

Depending on the metabolic state, the total cellular level of long-chain acyl-CoA is changing. These fluctuations are significant and may range from 5 to $160 \mu \mathrm{M}$ [71]. Approximately one half of long-chain acyl-CoAs are detected in microsomes.

The large size and charge of the CoA-SH molecule induce its transport to subcellular compartments, which depends on specific high-affinity transporters located on organelle membranes [36]. Human mitochondria contain solute carrier family 25 member 42 (SLC25A42), a transporter that exchanges $\mathrm{CoA}(\mathrm{CoA}-\mathrm{SH})$ for another adenine-containing substrate, including $3^{\prime}, 5^{\prime}$-ADP [72]. Moreover, SLC25A16 is likely to be a mitochondrial transporter for $\mathrm{CoA}-\mathrm{SH}$, although its activity has not been successfully reconstituted in vitro to date [23]. In mammalian peroxisomes, there are three members of ATP-binding cassette subfamily D, ABCD1-3, which mediated the transport of acyl-CoA [73,74]. Furthermore, it was demonstrated that SLC25A17 is localized in the peroxisomal membrane, and its main function is probably the transport of $\mathrm{CoA}-\mathrm{SH}, \mathrm{FAD}$, and $\mathrm{NAD}^{+}$into peroxisomes in exchange for intraperoxisomally generated PAP (adenosine $3^{\prime}, 5^{\prime}$-diphosphate), FMN, and AMP [75]. In the endoplasmic reticulum, the transporter AT-1 (acetyl-coenzyme A transporter) imports acetyl-CoA into the endoplasmic reticulum lumen in exchange for CoA-SH. Its downregulation results in widespread cell death and the induction of processes characteristic of autophagy [76].

\section{Protein CoAlation and Other Protein Modifications Related to CoA}

CoA-SH is involved in posttranslational modifications of proteins. On the one hand, it is a substrate in the phosphopantetheinylation process catalyzed by phosphopantetheinyl transferases. As a result of this reaction, $4^{\prime}$-phosphopantetheine is transferred from CoA-SH to serine residue of protein e.g., mitochondrial fatty acid synthase which results in an inactive apo-synthase being transformed into an active holo-synthase $[77,78]$. On the other hand, CoA-SH is a carrier of groups necessary for protein acetylation. The attachment of acetyl groups to the lysine residues is an important element in regulating the activity of many proteins. Acetylation affects the stability of the cytoskeleton elements and modulates the activity of several enzymes. It plays a particularly important role in regulating gene expression. In general, a high degree of histone acetylation correlates with increased transcriptional activity. The action of many different transcription factors and transcription co-regulators is modified by acetylation. These are the basic transcription factors such as TFIIB, but also proteins of specific cellular signal pathways such as $\mathrm{p} 53, \mathrm{NF}-\mathrm{kB}$ or $\mathrm{Rb}[79,80]$. Furthermore, CoA-SH can modify proteins by directly binding to cysteine residues [36].

Cysteine residues of proteins can form disulfides with low-molecular-weight thiols [81]. Such post-translational modifications generate different forms of proteins with various physicochemical properties and may also affect their functions and, in particular, modify their enzymatic activity $[82,83]$. Most organisms contain high concentrations of low-molecular-weight thiols. Glutathione (GSH) is the most abundant and ubiquitous of these compounds. Although $<0.1 \%$ of all cysteines in proteins are modified by GSH binding (glutathionylation) in non-stressed cells, this portion increases to $>15 \%$ in disulfide stress conditions [84]. Other important compounds from this group found in mammals include cysteine [84], homocysteine [85], and CoA-SH [36,84]. CoA-SH may covalently bind to cysteine residues in proteins, similar to glutathione, in a process called CoAlation [83,86-88]. 
Modification of cell proteins by CoAlation is stimulated in response to oxidative stress. Under stress conditions, cysteine thiol groups are oxidized to sulfenic acid, which facilitates the formation of disulfide bonds between cysteine residues and CoA-SH (and other low-molecular-mass thiols); this process may be effectively blocked by antioxidants $[36,86]$. It has also been shown that the level of CoAlation of proteins correlates with the concentration of CoA-SH in the cell [36]. CoAlation, similar to glutathionylation, is a reversible process, and protein de-CoAlation is a rapid event initiated immediately when oxidative stress is eliminated [86]. Although the mechanism of in vitro CoA-SH attachment is recognized as nonenzymatic, enzymes in the cell may be involved in this process. It was found that the removal of covalently attached CoA to proteins involves enzymes (CoAredoxins) [36]. In addition to oxidative stress, the increased CoAlation of proteins can also be caused by starvation in the rat liver. The opposite effect is caused by feeding rats for seven days with a high-fat and sucrose-rich diet. The CoAlation of proteins is also significantly lower in the liver of genetically obese ob/ob mice $[36,86]$.

More than 500 proteins in mammalian cells have been identified as CoAlated, and the majority $(>65 \%)$ are metabolic enzymes involved in major metabolic pathways, such as the tricarboxylic acid cycle, $\beta$-oxidation, ketone bodies, glucose and amino acid metabolism, in which CoA-SH and its derivatives are cofactors and metabolites. Among the proteins modified with $\mathrm{CoA}-\mathrm{SH}$, a significant pool consists of proteins that are also involved in stress response and protein synthesis $[36,86]$.

Cysteine residues modified by $\mathrm{CoA}-\mathrm{SH}$ are often located in protein sites that are functionally and structurally important and that are involved in many different biological functions, such as enzymatic catalysis, signal transduction, structure stabilization, and metal binding [36]. Below are some examples of proteins that undergo the devastation and the effects of this modification on their function. CoAlation of rat mitochondrial acetyl-CoA acetyltransferase transformed this enzyme into two partially active forms, with approximately $70 \%$ and $50 \%$ of the activity of the unmodified enzyme $[82,89,90]$. Under severe oxidative stress, the antioxidant enzymes, 2-Cys peroxiredoxin subclass Prdx5 are also CoAlated and lose their activity as a result [91]. Under oxidative stress, an increase in the CoAlation of pyruvate dehydrogenase kinase 2 (PDK2) in heart caused a decrease of its activity that leads to dephosphorylation of the pyruvate dehydrogenase (PDH) in pyruvate dehydrogenase complex (PDC) and increase of its activity [86]. The activity of Aurora A protein kinase, an enzyme overexpressed in various cancers, decreases upon CoAlation, and the inhibition of this kinase may be a new potential direction for the development of anticancer therapy [92].

In summary, CoAlation is a reversible process that is assumed to protect the cysteine residues in proteins from irreversible oxidation. It also regulates the activity of certain proteins whose cysteine residues are essential for their functioning. Among proteins susceptible to CoAlation stimulated by oxidative or metabolic stress, a high proportion of metabolic enzymes may represent the potential regulatory mechanism by which these functional pathways react to changes in the CoA/acyl-CoA ratio in the cell [86].

\section{CoA and Pathologies}

Diseases related to improper cellular concentrations of CoA-SH are not very common. This outcome is a result of Pan, being prevalent in most foods, and even ruminant microbiota produce enough Pan to adequately supply human organisms [31]. Thus, diseases related to improper CoA-SH levels are generally related to defects in the genes associated with CoA-SH synthesis, CoA-SH degradation or transport [93]. However, one paper described the inverse correlation between Pan intake and serum C-reactive protein concentration in human subjects and suggested that this correlation was associated with CoA-SH levels, but in this study, molecular level experiments were not performed [94]. Nevertheless, there are some well-characterized pathologies related to CoA-SH concentration. 


\subsection{Neurodegenerative Diseases}

Perhaps the best described disease associated with reduced cellular CoA-SH levels is pantothenate kinase-associated neurodegeneration (PKAN), also known as Hallervorden-Spatz disease, an autosomal recessive inherited disease caused by a mutation in the PANK2 gene. It was first described in 1922 by two physicians from Germany, Hallervorden and Spatz. This disease is characterized by neurodegeneration, iron accumulation in the brain, and variable neurological dysfunction. It is caused by specific mutation in the PANK2 gene that results in deficiency of the PANK2 enzyme, which leads to the accumulation of cysteine and the chelation of iron in the brain [95]. In vitro and animal studies confirmed that this disease is also associated with a decrease in CoA-SH and CoA thioesters in brain and liver cells $[78,96]$. The roles of CoA-SH levels in the development of PKAN have been presented in two recent papers. Lambrechts et al. [78] suggested that reduced CoA-SH biosynthesis leads to a reduction in active mitochondrial acyl carrier protein and the reduced lipoylation and activity of PDC. These findings were confirmed based on similar clinical features (e.g., progressive dystonia) of three other genetic diseases. Mutation of gene encoding another enzyme of the CoA-SH synthesis pathway, COASY, leads to CoA synthase protein-associated neurodegeneration (CoPAN), which is associated with partial loss of COASY activity. This disease has very similar clinical features to PKAN, including iron accumulation in the brain [97]. Two other CoA-related neurodegenerative diseases are not associated with CoA-SH synthesis: MePAN, which is caused by mutation of mitochondrial enoyl-[acyl carrier protein] reductase, a protein critical for lipoylation, and dihydrolipoyl transacetylase (PDC-E2) deficiency. All these pathologies result in decreased PDC activity [78]. Results from a study using a PKAN mouse model suggested another pathological mechanism of a disease that involves reduced succinyl-CoA levels and reduced expression of genes associated with heme and hemoglobin synthesis, which may lead to disruption of oxygen availability and/or redox balance in the brain [96]. CoA-SH supplementation prevented neuronal death in vitro suggesting that $\mathrm{CoA}-\mathrm{SH}$ treatment may be a possible therapeutic intervention for PKAN patients [98]. Recently, a new potential therapeutic approach for PKAN treatment was reported. An allosteric PANK activator from the pantazine group, PZ-2891, has been successfully used for PKAN treatment in a mouse model [99].

Variants of the COASY gene with near complete loss of function cause a subtype of pontocerebellar hypoplasia ( $\mathrm{PCH})$ [100]. $\mathrm{PCH}$ is a heterogeneous group of neurodegenerative diseases. Its clinical features include hypoplasia of the cerebellum and pons. Patients with biallelic COASY mutations develop prenatal PCH and die before or shortly after birth. In these patients, no stable COASY was produced in cells. Unfortunately, the CoA-SH levels were not measured in this study, but it is generally agreed that the synthesis of CoA-SH from Pan is the only source of CoA in the human body [100].

The risk of Alzheimer's disease (AD) development has been associated with single nucleotide polymorphisms (SNPs) in the COASY gene [101]. However, this study focused only on women with Down syndrome; therefore, this finding needs to be confirmed in the general population. Moreover, AD is associated with increased methylation of the COASY gene, which may lead to its decreased expression [102]. Cholinergic dysfunction in AD is caused by the reduced production of acetyl-CoA [103]. All these data suggest that alterations in CoA-SH synthesis may be involved in the development of AD.

Another neurodegenerative disorder, Huntington's disease (HD), seems to be associated with CoA-SH levels. Specifically, a post-mortem metabolomic study revealed decreased levels of Pan in the brains of HD patients [104]. Decreased Pan in the brain may cause myelin metabolism disorders that can lead to myelin loss in HD patients [6].

SLC25A42 is a CoA-SH transporter located in the inner mitochondrial membrane. Recently, two papers reported disease caused by mutations in the gene encoding SLC25A42 in Arab patients $[105,106]$. This disease presented with epileptic encephalopathy, developmental delay, myopathy and lactic acidosis. The intracellular total CoA level in fibroblasts isolated from these patients was decreased [105]. 


\subsection{Cancers}

Carcinogenesis is inextricably associated with substantial changes in cell metabolism. There is a significant amount of research indicating that changes to carbohydrate, nucleic acid, lipid, and amino acid metabolism are critical in the development, progression, and metastasis of many types of cancers $[19,107,108]$. There is also growing evidence that pathways of CoA-SH biosynthesis can undergo severe changes in cancer cells. However, most of the research is focused on genetic level data, and few mention CoA-SH level.

Some research has shown that increased levels of CoA-SH are toxic to cancer cells, including breast, cervical, and liver cancer cells. Cell cultures showed inhibited growth after $24 \mathrm{~h}$ of incubation with $100 \mu \mathrm{M}$ CoA-SH. Unfortunately, at the same time- and dose-range, CoA-SH was found to be equally toxic to normal cells; therefore, the potential of using $\mathrm{CoA}-\mathrm{SH}$ as a therapeutic agent is limited [109]. On the other hand, a decrease in the level of CoA-SH can be tolerated very well by cancer cells. Lowering the level of CoA-SH by $50 \%$ did not change cell viability; however, notably, these cells were monitored for only 8 days in this study [110].

The abnormal biosynthesis and homeostasis of CoA-SH can lead to dysregulated CoAlation of Aurora A kinase. This kinase controls meiosis, mitosis, and cell division, thus, it is associated with various types of cancer. The overexpression of Aurora A was detected in leukemia, breast, prostate, and colon cancers [111]. It has been shown that CoA-SH binds directly to Aurora A and inhibits its catalytic activity in a dose-dependent manner [92]. The link between CoA-SH level and Aurora A action suggests interesting possibilities for a new therapeutic approach.

Acute myeloid leukemia (AML) is characterized by broad heterogeneous genetic alterations. Recently, two new genetic markers of AML in CoA-SH biosynthesis pathways were proposed: PANK2 and PANK4. Overexpressed PANK2 was a favorable prognostic factor, while high expression of PANK4 was associated with a low survival rate [112]. The possible mechanisms behind these effects are still unclear and require further investigation. It has been proven that PANK4 can inhibit pro-caspase-9 expression; therefore, it is possible that, by suppressing cell apoptosis, PANK4 leads to shorter survival of patients with AML [113]. Of these two genes, only the proteins encoded by PANK2 have functional pantothenate kinase activity; however, researchers did not analyze the CoA-SH level in tissues or serum [31]. Furthermore, a VNN1 gene was proposed for improving therapy outcomes and as relapse risk biomarker. Higher expression of VNN1 was associated with poor outcomes, including resistance to chemotherapy and shorter relapse periods [114].

On the molecular level, breast cancer is divided into subtypes based on the expression level of estrogen receptor (ER), progesterone receptor (PR), and human epidermal growth factor receptor 2 (HER2). An increasing number of studies have investigated the genomic and transcriptomic architectures of these subtypes, but few incorporated CoA-SH biosynthesis genes into the analyses. Nagai et al. discovered a significantly higher expression of PANK3 in ER+/PR+ primary breast tumors than in ER-/PR- samples [115]. Unfortunately, no other types of breast cancer were analyzed, and no comparison to normal tissue was performed. It is also unclear whether a higher expression of PANK3 is correlated with a higher CoA-SH level. The data from in vitro experiments suggested that PANK2 is downregulated by estrogen receptor $\beta$; however, this observation has not been confirmed in human tissues [116]. The expression pattern of COASY in breast cancer cells was not compared to that in normal cells; however, some studies have reported that knocking out COASY in triple-negative breast cancer (ER-/PR-/HER2-) resulted in reduced cell proliferation and migration. Interestingly, the effect was achieved only in RNAi-knockdown models, and knocking down COASY with inducible shRNA had no effect on cell proliferation [110]. Furthermore, knocking down COASY by siRNA sensitized HER2+ (ER $\pm / P R \pm / H E R+)$ breast cancer cells to trastuzumab treatment [117]; however, this effect needs to be verified in in vivo models. Standard chemotherapy for breast cancer, regardless of ER/PR.HER2 status damages the ovaries, causing temporary or permanent chemotherapy-related amenorrhea (CRA) in many women who survive cancer [118]. Unfortunately, the currently available methods for predicting preservation of ovarian function after cancer treatment are inadequate [119]. Recently, 
a novel genetic predictor of CRA based on CoA metabolism was proposed. Specific SNPs of PPCDC can be related to lower chances of menses after chemotherapy [120].

Colorectal cancer is one of the most common cancers and one of the most common causes of cancer-related death worldwide [121]. Although radiation and neoadjuvant concurrent chemoradiotherapy are currently the gold standard therapies, no validated biomarkers or molecular targets to predict or improve patient response have been identified. Recently, COASY was proposed as a predictive marker for radiation resistance. In vitro and in vivo studies proved that increased levels of COASY were directly related to radiation resistance, possible by enhancing DNA repair efficiency and/or by activation of the PI3K/AKT/mTOR pathway. Knocking down COASY resulted in a better radiation response, including delayed tumor growth, inhibited cell proliferation, and increased activation of apoptosis after irradiation [122,123]. It would be interesting to know whether heterogeneity in response to radiation alterations in COASY expression levels is characteristic of other types of cancers. Another gene from the CoA-SH metabolism pathway, VNN1, was proposed as a marker for the response to preoperative neoadjuvant concurrent chemoradiotherapy (CCRT). Studies have shown that high expression of VNN1 is associated with poor response to CCRT and an adverse prognosis [124]. However, VNN1 promotion of tumor progression seems to be more closely related to oxidative stress conditions than to CoA-SH metabolism [125]. Moreover, VNN1 and six other genes were proposed for inclusion in a blood-based biomarker panel for colorectal cancer risk assessment, which showed a very high rate of accuracy, sensitivity, and specificity [126,127].

In CoA-SH biosynthesis genes, noncoding RNAs can play roles in cancer. A microRNA-107 (miR-107) of intron 5 of PANK1 is a posttranscriptional regulator of genes involved in adipogenesis, hypoxia, cell cycle arrest, and angiogenesis; therefore, its dysregulation may be a key factor underlying tumorigenesis. The expression level of miR-107 was found to be reduced in non-small cell lung cancer (NSCLC) and oesophageal cancer [128,129]. In contrast, miR-107 was overexpressed in pancreatic cancer and breast cancer $[130,131]$. In vitro studies suggest that miR-107, by targeting cyclin-dependent kinase 8 (CDK8), can regulate chemosensitivity to cisplatin and can be used to predict a patient's response to chemotherapy [132].

\subsection{Colitis}

Recently, Roedriger re-examined pig experiments published in 1943 [133,134]. Pigs may have Pan deficiency, and therefore, feeding pigs a diet free of Pan resulted in the induction of colitis [134]. In humans, Pan deficiency is not found, but it is possible that lower levels of CoA-SH may be associated with the development of colitis. Some experimental data support this supposition. First, colonocyte energy metabolism is highly dependent on butyrate $\beta$-oxidation, for which CoA-SH is needed. Second, bacterial metabolites, nitric oxide and hydrogen sulfide, can lower the concentration of CoA-SH in colon mucosa [133]. SMVT encoded by the SLC5A6 gene is critical for the intestinal absorption of biotin and Pan. Mice with the SLC5A6 gene knocked out developed colitis. However, supplementation with high doses of biotin and Pan reversed this effect [27]. Another study suggested roles for CoA-SH levels in the development of colitis, but unfortunately, the authors did not measure the concentrations of CoA-SH in the experimental mice. In the colon tissue of patients with inflammatory bowel disease (IBD), VNN1, an enzyme of the exogenous CoA-SH degradation pathway, is overexpressed [135]. Moreover, this study showed that 3 SNPs of VNN1 are associated with the risk of IBD. However, the association of VNN1 expression and IBD may not be directly related to CoA-SH levels but may relate to the production of cysteamine, which is involved in the regulation of inflammation in the gut [135].

\subsection{Myopathies}

It seems that CoA-SH plays a very important role in muscle metabolism. First, it is required for the activation of fatty acids, which are energy sources for muscle, because fatty acids undergo $\beta$-oxidation. Furthermore, malonyl-CoA serves as the regulator of fatty acid transport in the mitochondria, which is 
a rate-limiting step of fatty acid oxidation. It was shown that the plasma concentration of Pan rises with exercise [136]. However, data on the role of CoA-SH concentrations in muscle are very scarce. Overexpressed human PANK2 gene in mice, which resulted in increased total CoA levels in muscle, led to reduced muscle performance and strength [137]. This outcome was associated with increased oxidative stress. Therefore, this study suggests that excessively increased total CoA levels in muscle may be detrimental to muscle function [137]. However, human subjects with mutations in the gene encoding the mitochondrial transporter of CoA-SH, SLC25A42 presented with myopathy [23]. Thus, $\mathrm{CoA}-\mathrm{SH}$ levels that are too low in mitochondria and $\mathrm{CoA}-\mathrm{SH}$ synthesis that produces excessive $\mathrm{CoA}-\mathrm{SH}$ levels both seem to be detrimental to muscle function. Moreover, it was hypothesized that the dilated cardiomyopathy and skeletal myopathy observed in Barth Syndrome (BTHS) are connected with the compromised tissue supply of CoA-SH, and treatment with Pan has been proposed. However, except for one case study from the 1990s, no publications have confirmed the benefits of Pan [138]. Rugulotto et al. [139] tried to replicate the experiment, but for three BTHS patients, this therapy was not as beneficial as was previously claimed. Thus, the treatment of BTHS patients with long-term Pan supplementation remains controversial.

\subsection{Infectious Diseases}

CoA-SH synthesis is also important for the survival and/or growth of numerous organisms that infect humans, including parasites, fungi, and bacteria.

Early studies have shown that in erythrocytes infected with malaria parasites, the level of CoA-SH is higher than in normal erythrocytes [140]. Further studies have proven that human malaria parasites can independently synthesize CoA-SH but require an exogenous supply of Pan for survival [141-143]. These findings resulted in the development of antiplasmodial Pan analogs that kill the parasite by depriving it of CoA-SH or inhibiting CoA-utilizing metabolic processes [144-146]. However, recent studies have shown that certain types of mutations in pantothenate kinase of Plasmodium falciparum resulted in diverse sensitivity for Pan analogs, from hypersensitive to resistant [145]. This suggests that CoA-SH metabolism can be used as a potential target of antimalarial drugs in combination therapies.

In terms of malaria, host CoA-SH metabolism is also important. Studies have shown that the levels of activity and/or expression of pantetheinase (an enzyme in the CoA-SH degradation pathway that produces Pan and cysteamine from pantetheine, encoded by $V N N$ genes, see Figure 2) contribute to the susceptibility and severity of malaria [23]. Mouse strains with VNN mRNA expression and pantetheinase protein activity in tissues at undetectable levels showed higher parasitemia compared to their wild type counterparts [147]. Lower activity of pantetheinase leads to lower levels of anti-plasmodial cysteamine [148]. Moreover, a reduced level of serum pantetheinase activity predisposes patients to severe and complicated forms of malaria, including cerebral malaria and severe anemia, due to the diminished half-life of erythrocytes [49]. These findings seem to argue that the parasite depends on the host supply of Pan; therefore, a lower level of Pan would not be expected to benefit to Plasmodium. However, researchers have speculated that the effects of pantetheinase activity on the growth of the malaria-causing parasite might vary at different stages of infection. Unfortunately, none of these studies assessed how changes in enzyme activity from the degradation pathway of CoA-SH influence CoA-SH levels.

In animal models, pantetheinase deficiency reduced the negative impact of inflammation resulting from pathogen infection on host fitness. In two models, schistosomiasis and rickettsiosis, undetectable levels of $V N N$ expression resulted in increased survival and tolerance for the disease [149]. After Schistosoma infection, mice with VNN knocked out showed better controlled inflammatory reactions and attenuated intestinal injury [150]. In the case of Rickettsia infection, VNN-knockout mice exhibited decreased formation of granulomas in the spleen and liver [151].

An increasing number of multidrug-resistant bacterial strains have created an emerging need for the development of novel antibiotic strategies, and CoA metabolism can be a novel antimicrobial target. 
During recent decades, a number of studies have reported that pantothenamides (analogs of Pan) possess activity against gram-positive and gram-negative bacteria, including Escherichia coli, Staphylococcus aureus, methicillin-resistant S. aureus (MRSA), Staphylococcus epidermidis, Streptococcus pneumoniae, Streptococcus pyogenes, Pseudomonas aeruginosa, Mycobacterium avium, Mycobacterium abscessus, and Mycobacterium kansasii. Pantothenamides can act as inhibitors (either competitive or allosteric) of pantothenate kinase [152-155], causing cellular depletion of CoA-SH, or as substrates for pantothenate kinase, creating $\mathrm{CoA}$ analogs that disrupt CoA-dependent reactions (e.g., bacterial fatty acid biosynthesis) [156-158]. Nonetheless, these compounds have never been tested in vivo due to their instability in serum. It became apparent that human serum pantetheinase, an enzyme that normally degrades pantetheine, can also hydrolyze pantothenamides. Researchers are trying to overcome this problem with two different approaches: one is based on developing stable pantothenamides that are pantetheinase-resistant, and the other is based on using a combination of pantothenamides and pantetheinase inhibitors $[154,159]$. Both strategies have shown promising results in in vitro testing.

\subsection{Diabetes}

Studies have shown that total CoA levels in the liver and heart of diabetic rats and mice are higher than those in healthy rats and mice [160,161]. Moreover, in ob/ob mice (well-established models of human type 2 diabetes mellitus (DM2)), PANK1 deficiency leads to reduced serum insulin, improved insulin tolerance, and reduced fasting blood glucose [162].

MicroRNAs have been reported to play important roles in the pathophysiology of DM2 [163,164]. Studies have shown that microRNA-103 (miR-103) and miR-107, both located in PANK genes, play important roles in insulin sensitivity. In ob/ob mice, the expression of miR-103 and miR-107 in liver and adipose tissue is elevated. Silencing miR-107/103 in the liver resulted in improved glucose homeostasis and insulin sensitivity, whereas silencing miR107/103 in adipocytes resulted in upregulated expression of caveolin-1, which activates insulin signaling, probably by stabilizing caveolae-associated insulin receptors $[165,166]$. Moreover, circulating miR-103 has been recently proposed as an early marker of prediabetes mellitus stage [167].

\subsection{Other Diseases}

In the majority of cases, the underlying pathogenic mechanisms that lead to autism spectrum disorders are complex and not very well defined. There is growing evidence that gene dosage changes (changes in the number of copies of a particular gene) can contribute to the etiology of autism. Some of the copy number variants described in patients with autism are related to an alteration in the PPCDC gene [168]. Changes in the copy number of the PPCDC gene can result in mitochondrial defects that can affect synaptic function and result in neuropsychiatric symptoms [169].

In experiments, obese mice in the fed state had twice the total CoA levels in the liver and skeletal muscle than their nonobese littermates. Moreover, during fasting, an increase in total CoA level was observed only in the nonobese group, [170]. Of all PANK genes, only the expression of PANK1 was upregulated in the liver of the obese mice.

\section{Single-Nucleotide Polymorphisms in Genes Involved in CoA Metabolism}

Genes involved in CoA-SH biosynthesis and degradation pathways seem to exert a variable effect on human traits, including under pathological conditions. Genome-wide association studies (GWAS) have provided great opportunities to discover relationships between SNPs in genes and various metabolic phenotypes. However, in the case of CoA-SH biosynthesis and degradation pathways, much remains unknown. Only a few genes in the CoA-SH biosynthesis and degradation pathway have shown some associations with biological traits (Table 4). Moreover, according to the GWAS catalogue (an online database of SNP-trait associations), no associations have been discovered to date between SNPs in genes not involved directly in CoA metabolism and CoA-SH levels [171]. This lack of information suggests a new research opportunity. 
Table 4. Traits associated with genetic variants of CoA biosynthesis and degradation enzymes. IGFBP3-insulin-like growth factor-binding protein 3, BMI-body mass index, AD—Alzheimer's disease, and IBD—inflammatory bowel disease.

\begin{tabular}{|c|c|c|c|c|c|c|}
\hline Enzyme & Gene & SNP Variant & $\begin{array}{l}\text { Associated } \\
\text { Trait } \\
\end{array}$ & Nature of Change & Tested Population & Reference \\
\hline \multirow{7}{*}{ Pantothenate kinase } & \multirow{2}{*}{ PANK1 } & rs11185790-A & Insulin level & Decreased insulin level & European & [172] \\
\hline & & rs7073802-A & $\begin{array}{l}\text { Educational } \\
\text { attainments }\end{array}$ & $\begin{array}{l}\text { Increased self-reported } \\
\text { math ability }\end{array}$ & European & [173] \\
\hline & PANK3 & rs35693458-A & $\begin{array}{l}\text { Unipolar } \\
\text { depression }\end{array}$ & $\begin{array}{l}\text { Increased probability of } \\
\text { major depressive disorder } \\
\text { in individuals not } \\
\text { exposed to trauma }\end{array}$ & European & [174] \\
\hline & \multirow{4}{*}{ PANK4 } & rs12073504-G & $\begin{array}{l}\text { Obesity-related } \\
\text { trait }\end{array}$ & Increased IGFBP3 & Latin American & [175] \\
\hline & & rs7535528-G & BMI & Increased BMI & $\begin{array}{l}\text { East Asian, African } \\
\text { American, European, } \\
\text { South Asian, } \\
\text { Latin American }\end{array}$ & [176] \\
\hline & & rs7535528-A & BMI & Decreased BMI & European & [177] \\
\hline & & rs7535528-A & Neuroticism & Increased irritability & European & [178] \\
\hline \multirow{4}{*}{$\begin{array}{l}\text { Phosphopantothenoylcysteine } \\
\text { decarboxylase }\end{array}$} & \multirow{4}{*}{$P P C D C$} & rs2120019-C & $\begin{array}{l}\text { Blood trace } \\
\text { element }\end{array}$ & $\begin{array}{l}\text { Decreased serum } \\
\text { Zn levels }\end{array}$ & European & [179] \\
\hline & & $\begin{array}{l}\text { rs12148488-T } \\
\text { rs8042558-T }\end{array}$ & $\begin{array}{c}\text { Coffee } \\
\text { consumption }\end{array}$ & Decreased consumption & European & {$[180,181]$} \\
\hline & & rs147451859-G & $\begin{array}{l}\text { Response to } \\
\text { chemotherapy }\end{array}$ & $\begin{array}{l}\text { Adverse response to } \\
\text { antineoplastic agent in } \\
\text { breast cancer }\end{array}$ & European & [120] \\
\hline & & rs12148488-G & $\begin{array}{c}\text { Blood } \\
\text { pressure }\end{array}$ & $\begin{array}{l}\text { Decreased mean } \\
\text { arterial pressure }\end{array}$ & $\begin{array}{l}\text { African American, } \\
\text { Latin American, } \\
\text { European }\end{array}$ & [182] \\
\hline \multirow[t]{2}{*}{ Coenzyme A synthase } & \multirow[t]{2}{*}{ COASY } & rs668799-T & $\begin{array}{l}\text { Medication } \\
\text { use }\end{array}$ & $\begin{array}{l}\text { Increased drugs used } \\
\text { in diabetes }\end{array}$ & European & [183] \\
\hline & & rs598126-T & $\mathrm{AD}$ & Increased risk of $\mathrm{AD}$ & American & [101] \\
\hline Pantetheinase & VNN1 & $\begin{array}{l}\text { rs3756975-C } \\
\text { rs } 13204527-\mathrm{T} \\
\text { rs } 909977-\mathrm{T}\end{array}$ & IBD & Increased risk of IBD & European & [135] \\
\hline
\end{tabular}

\section{CoA and Its Precursor Pantethine as Circulating Lipid-Lowering Supplemental Agents}

Since CoA-SH plays a key role in lipid metabolism, especially in fatty acid oxidation, scientists have hypothesized that $\mathrm{CoA}-\mathrm{SH}$ or its precursor supplementation might reduce circulating lipid concentration. Indeed, it has been reported that the combination of $\mathrm{CoA}-\mathrm{SH}$ (used at pharmacological doses) with a moderate dose of a statin was more effective in curing patients with mixed dyslipidemia than statin monotherapy [184]. Moreover, it has been shown that combined CoA-SH and statin therapy was more effective in improving triacylglycerol, total cholesterol, and non-HDL-cholesterol concentrations than statin alone in patients with metabolic syndrome and mixed hyperlipidemia [185].

Much more attention has been given to pantethine (a CoA-SH precursor) as a circulating lipid-lowering compound than to CoA-SH. Pantethine, a stable form of pantetheine (two molecules of pantetheine linked by a disulfide bridge) as a dietary supplement (used at a pharmacological dose of 600-1200 mg per day), lowers elevated levels of total cholesterol, LDL-cholesterol, triacylglycerol, and non-HDL-cholesterol concentrations [186-188]. The effect of orally administered pantethine also results in: (a) an increase in HDL cholesterol concentration; and (b) normalization of apolipoprotein B (apo B) and apolipoprotein A (apoA); however, the effect depends on the type of dyslipidemia [189-191].

Some data suggest that CoA-SH (used at $400 \mathrm{U}$ per day) can improve blood triacylglycerol and lipoprotein concentrations (total cholesterol and non-HDL cholesterol were significantly reduced, and HDL cholesterol was increased) to a greater extent than pantethine (used at $600 \mathrm{U}$ per day) [192].

Taken together, the results published thus far indicate that $\mathrm{CoA}-\mathrm{SH}$ and pantethine can be useful in lowering elevated levels of circulating lipids in some diseases. This effect is most impressive when pantethine side effect and toxicity (practically none, when used at concentrations effectively lowering blood lipid concentration) are compared with commonly used drugs that lower circulating lipids 
(for instance, statins). However, the effect of CoA-SH or pantethine on circulating lipids is relatively slow. Usually, a maximal effect is observed at 4 months but may take up as long as 6-9 months.

The exact molecular mechanism of action of CoA-SH and pantethine on blood lipid concentration is unknown. Although pantethine is a precursor for vitamin B5 synthesis and intake of the pharmacological dose of pantethine results in higher circulating vitamin B5 concentration, the production of vitamin B5 is not the mechanism of action because intake of panthotenic acid does not have the same effect on serum lipid concentration [2]. Pantethine-induced inhibition of acetyl-CoA carboxylase by cysteamine, the product of pantethine and CoA degradation, and inhibition of HMG-CoA reductase and cholesterol synthesis in isolated hepatocytes by pantethine may explain, at least in part, the fact that pantethine (and possibly $\mathrm{CoA}-\mathrm{SH}$ ) administration in pharmacological doses is effective in reducing plasma triacylglycerol and cholesterol (total cholesterol, LDL-cholesterol, and non-HDL-cholesterol) concentrations [193-195].

Pantethine (specifically, the cysteamine formed from pantethine) inhibition of acetyl-CoA carboxylase decreases the level of malonyl-CoA, which is (a) a substrate for fatty acid synthesis; and (b) an allosteric inhibitor of CPT1, a key regulator of fatty acid oxidation. Consequently, this reduction of malonyl-CoA leads to (a) a decrease in fatty acid synthesis; and (b) an increase in fatty acid oxidation in mitochondria. In turn, plasma lipids are affected, especially by triacylglycerol-lowering effects.

However, another mechanism is not excluded. Considering that (a) gut microbiota (especially bacterial strains such Lactobacillus and Bifidobacterium) aid in decreasing lipids in hyperlipidemic patients; and (b) pantethine promotes the survival and growth of various beneficial gut bacteria; it has been suggested that microbiota can contribute (at least in part) to a possible mechanism of pantethine action on circulating lipids [188,194-199].

Pantethine supplementation also has some beneficial effects on parameters associated with platelet lipid composition and cell membrane fluidity. In diabetic patients, the lipid composition of platelets is significantly different than that of healthy subjects. Supplementation with pantethine normalizes platelet fatty acid composition to a control value, leading to a significant reduction in platelet hyperaggregation [200]. Moreover, pantethine inhibits lipid peroxidation of the LDL-cholesterol fraction and consequently reduces lipid deposition, intimal thickening, and fatty streak formation in the aorta and coronary artery [201]. The metabolic effects of pantethine are summarized in Figure 4.

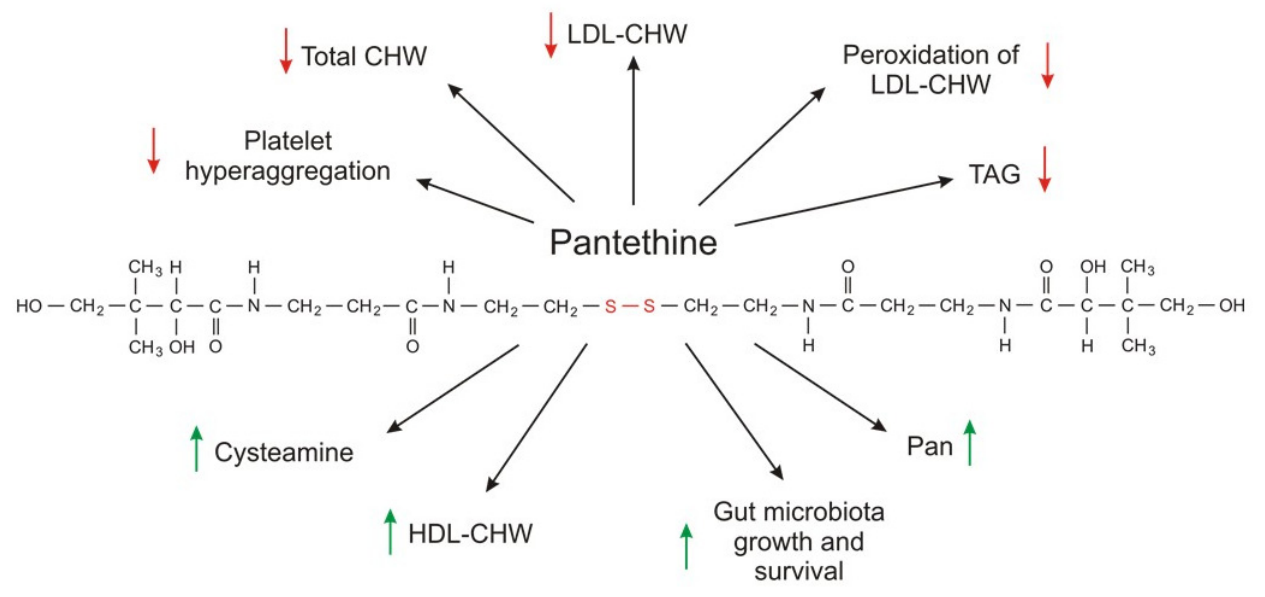

Figure 4. The metabolic effects of pantethine. Red arrows indicate decrease; green arrows indicate increase.

Although several clinical trials have shown that $\mathrm{CoA}-\mathrm{SH}$ and especially pantethine used at pharmacological doses reduce circulating lipid levels in patients with dyslipidemia associated with different pathologies, it seems that additional studies are necessary to determine whether CoA-SH or pantethine supplementation has a beneficial effect on cardiovascular risk markers independently of 
or in combination with a healthy diet. Moreover, further research is also needed to explain the exact molecular mechanism of CoA-SH and pantethine action on circulating lipid concentration. At present, it is safe to say that administration of CoA-SH is not entirely different from the administration of pantethine because in the end both compounds are converted to Pan and cysteamine.

\section{Conclusions and Further Perspectives}

The key roles of CoA-SH in cell metabolism have been well documented. However, further studies are required to address the following areas of interest: (a) the significance of changes in CoA-SH levels under pathological conditions, including neurodegenerative diseases, cancers, colitis, myopathies, infectious diseases, diabetes; and (b) the potential role of CoA-SH and pantethine as dietary supplements lowering circulating lipids.

Author Contributions: Conceptualization, T.S., E.S.; writing—original draft preparation, A.C., S.S.-J., A.H., J.T., T.S., E.S.; writing—review and editing, A.C., T.S., E.S., J.S.; supervision, T.S., J.S. All authors have read and agreed to the published version of the manuscript.

Funding: This research was funded by ST-40, ST-41 and National Science Centre of Poland, grant number 2016/22/E/NZ4/00665.

Conflicts of Interest: The authors declare no conflict of interest. The funders had no role in the design of the study; in the collection, analyses, or interpretation of data; in the writing of the manuscript, or in the decision to publish the results.

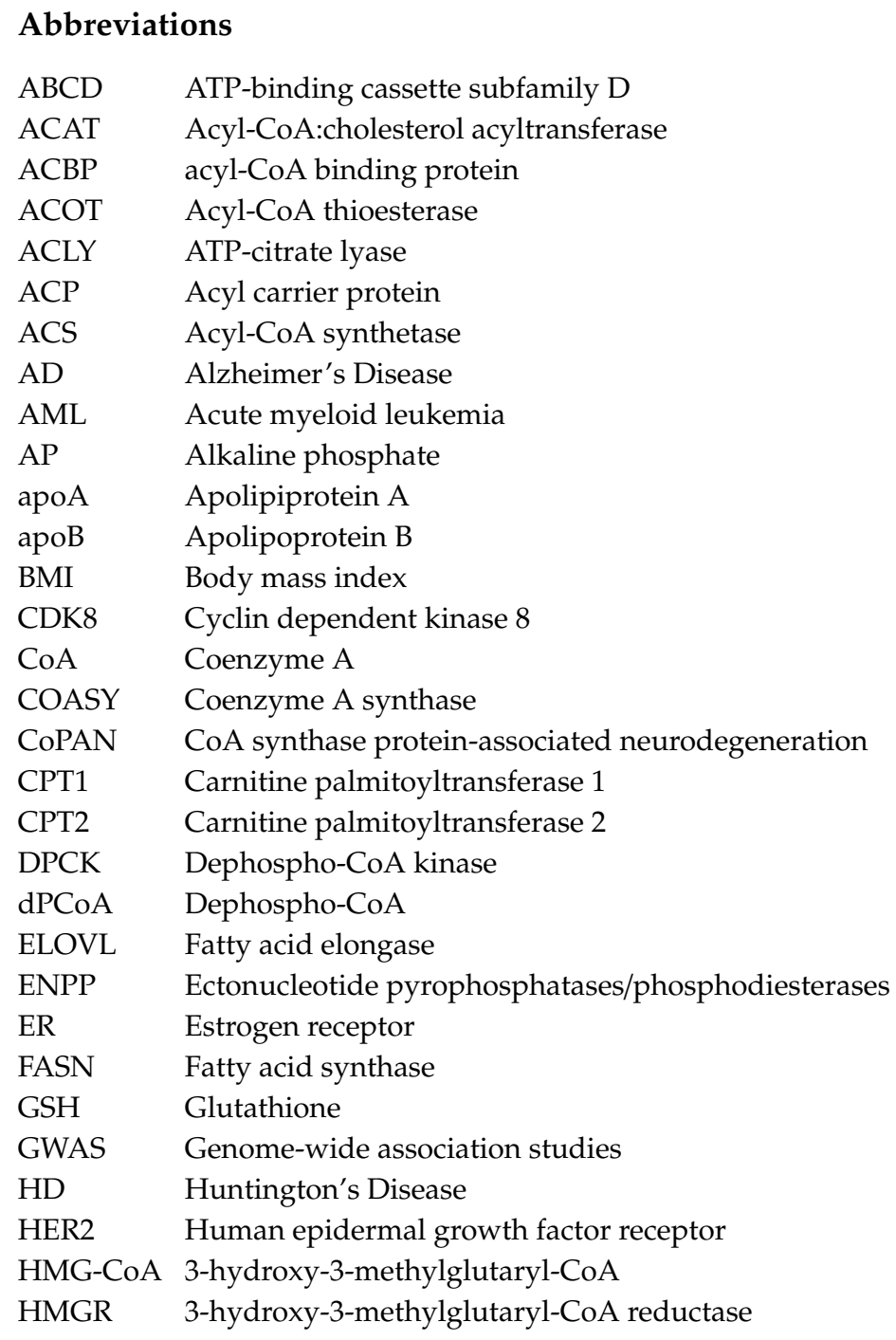




$\begin{array}{ll}\text { IBD } & \text { Inflammatory bowel disease } \\ \text { IGFBP3 } & \text { Insulin-like growth factor-binding protein } \\ \text { IMM } & \text { Inner mitochondrial membrane } \\ \text { LAP } & \text { Lysosomal acid phosphatase } \\ \text { NSCLC } & \text { Non-small cell lung cancer } \\ \text { NUDT } & \text { Nucleoside diphosphate linked moiety X-type motif } \\ \text { OMM } & \text { Outer mitochondrial membrane } \\ \text { Pan } & \text { Pantothenate, pantothenic acid } \\ \text { PANK } & \text { Pantothenate kinase } \\ \text { PCH } & \text { Pontocerebellar hypoplasia } \\ \text { PDC } & \text { Pyruvate dehydrogenase complex } \\ \text { PDK } & \text { Pyruvate dehydrogenase kinase } \\ \text { PKAN } & \text { Pantothenate Kinase Associated Neurodegeneration } \\ \text { PPan } & \text { 4'phosphopantothenate } \\ \text { PPanSH } & \text { 4'-phosphopantetheine } \\ \text { PPCDC } & \text { Phosphopantothenoylcysteine decarboxylase } \\ \text { PPCS } & \text { Phosphopantothenoylcysteine synthetase } \\ \text { PPT } & \text { Palmitoyl-protein thioesterase } \\ \text { PR } & \text { Progesterone receptor } \\ \text { ROS } & \text { Reactive oxygen species } \\ \text { SLC25A42 } & \text { Solute Carrier Family 25 Member 42 } \\ \text { SMVT } & \text { Sodium dependent multivitamin transporter } \\ \text { SNP } & \text { Single nucleotide polymorphisms } \\ \text { VNN } & \text { Pantetheinase }\end{array}$

\section{References}

1. Lykstad, J.; Sharma, S. Biochemistry, Water Soluble Vitamins; StatPearls Publishing: Treasure Island, FL, USA, 2019.

2. Miller, J.W.; Rucker, R.B. Pantothenic Acid. Present Knowledge in Nutrition, 10th ed.; Wiley-Blackwell: Hoboken, NJ, USA, 2012; pp. 375-390.

3. Gheita, A.A.; Gheita, T.A.; Kenawy, S.A. The potential role of B5: A stitch in time and switch in cytokine. Phyther. Res. 2020, 34, 306-314. [CrossRef] [PubMed]

4. Patassini, S.; Begley, P.; Xu, J.; Church, S.J.; Kureishy, N.; Reid, S.J.; Waldvogel, H.J.; Faull, R.L.M.; Snell, R.G.; Unwin, R.D.; et al. Cerebral Vitamin B5 (D-Pantothenic Acid) Deficiency as a Potential Cause of Metabolic Perturbation and Neurodegeneration in Huntington's Disease. Metabolites 2019, 9, 113. [CrossRef] [PubMed]

5. Yale, K.; Juhasz, M.; Mesinkovska, N.A. Medication-Induced Repigmentation of Gray Hair: A Systematic Review. Ski. Appendage Disord. 2020, 6, 1-10. [CrossRef] [PubMed]

6. Ismail, N.; Kureishy, N.; Church, S.J.; Scholefield, M.; Unwin, R.D.; Xu, J.; Patassini, S.; Cooper, G.J.S. Vitamin B5 (D-pantothenic acid) localizes in myelinated structures of the rat brain: Potential role for cerebral vitamin B5 stores in local myelin homeostasis. Biochem. Biophys. Res. Commun. 2020, 522, 220-225. [CrossRef] [PubMed]

7. Ridgway, N.D.; Mcleod, R.S. (Eds.) Biochemistry of Lipids, Lipoproteins and Membranes; Elsevier: Amsterdam, The Netherlands, 2016.

8. Anderson, G.; Reiter, R.J. Melatonin: Roles in influenza, Covid-19, and other viral infections. Rev. Med. Virol. 2020, 30, e2109. [CrossRef]

9. Theodoulou, F.L.; Sibon, O.C.M.; Jackowski, S.; Gout, I. Coenzyme A and its derivatives: Renaissance of a textbook classic. Biochem. Soc. Trans. 2014, 42, 1025-1032. [CrossRef]

10. Van der Sluis, R.; Erasmus, E. Xenobiotic/medium chain fatty acid: CoA ligase-A critical review on its role in fatty acid metabolism and the detoxification of benzoic acid and aspirin. Expert Opin. Drug Metab. Toxicol. 2016, 12, 1169-1179. [CrossRef]

11. Gout, I.; Coenzyme, A. A protective thiol in bacterial antioxidant defence. Biochem. Soc. Trans. 2019, 47, 469-476. [CrossRef] 
12. Bhandary, S.; Aguan, K. Pyruvate dehydrogenase complex deficiency and its relationship with epilepsy frequency-An overview. Epilepsy Res. 2015, 116, 40-52. [CrossRef]

13. UniProt. Available online: https://www.uniprot.org/ (accessed on 25 September 2020).

14. Ruetz, M.; Campanello, G.C.; Purchal, M.; Shen, H.; McDevitt, L.; Gouda, H.; Wakabayashi, S.; Zhu, J.; Rubin, E.J.; Warncke, K.; et al. Itaconyl-CoA forms a stable biradical in methylmalonyl-CoA mutase and derails its activity and repair. Science 2019, 366, 589-593. [CrossRef]

15. Pietrocola, F.; Galluzzi, L.; Pedro, J.M.B.-S.; Madeo, F.; Kroemer, G. Acetyl coenzyme A: A central metabolite and second messenger. Cell Metab. 2015, 21, 805-821. [CrossRef]

16. Foster, D.W. Malonyl-CoA: The regulator of fatty acid synthesis and oxidation. J. Clin. Investig. 2012, 122, 1958-1959. [CrossRef]

17. Zabielska, J.; Sledzinski, T.; Stelmanska, E. Acyl-coenzyme A: Cholesterol acyltransferase inhibition in cancer treatment. Anticancer Res. 2019, 39, 3385-3394. [CrossRef]

18. Stelmanska, E.; Swierczynski, J. Up-regulation of lipogenic enzyme genes expression in inguinal white adipose tissue of female rats by progesterone. J. Steroid Biochem. Mol. Biol. 2013, 134, 37-44. [CrossRef]

19. Swierczynski, J.; Hebanowska, A.; Sledzinski, T. Role of abnormal lipid metabolism in development, progression, diagnosis and therapy of pancreatic cancer. World J. Gastroenterol. 2014, 20, 2279-2303. [CrossRef]

20. Shi, L.; Tu, B.P. Acetyl-CoA and the regulation of metabolism: Mechanisms and consequences. Curr. Opin. Cell Biol. 2015, 33, 125-131. [CrossRef]

21. Bekeova, C.; Anderson-Pullinger, L.; Boye, K.; Boos, F.; Sharpadskaya, Y.; Herrmann, J.M.; Seifert, E.L. Multiple mitochondrial thioesterases have distinct tissue and substrate specificity and CoA regulation, suggesting unique functional roles. J. Biol. Chem. 2019, 294, 19034-19047. [CrossRef]

22. Mariño, G.; Pietrocola, F.; Eisenberg, T.; Kong, Y.; Malik, S.A.; Andryushkova, A.; Schroeder, S.; Pendl, T.; Harger, A.; Niso-Santano, M.; et al. Regulation of Autophagy by Cytosolic Acetyl-Coenzyme A. Mol. Cell 2014, 53, 710-725. [CrossRef] [PubMed]

23. Naquet, P.; Kerr, E.W.; Vickers, S.D.; Leonardi, R. Regulation of coenzyme A levels by degradation: The 'Ins and Outs'. Prog. Lipid Res. 2020, 78, 101028. [CrossRef] [PubMed]

24. Srinivasan, B.; Baratashvili, M.; Van Der Zwaag, M.; Kanon, B.; Colombelli, C.; Lambrechts, R.A.; Schaap, O.; Nollen, E.A.; Podgoršek, A.; Kosec, G.; et al. Extracellular 4'-phosphopantetheine is a source for intracellular coenzyme A synthesis. Nat. Chem. Biol. 2015, 11, 784-792. [CrossRef]

25. Shibata, K.; Gross, C.J.; Henderson, L.M. Hydrolysis and absorption of pantothenate and its coenzymes in the rat small intestine. J. Nutr. 1983, 113, 2107-2115. [CrossRef]

26. Magnúsdóttir, S.; Ravcheev, D.; De Crécy-Lagard, V.; Thiele, I. Systematic genome assessment of B-vitamin biosynthesis suggests cooperation among gut microbes. Front. Genet. 2015, 6, 148. [CrossRef]

27. Sabui, S.; Kapadia, R.; Ghosal, A.; Schneider, M.; Lambrecht, N.W.G.; Said, H.M. Biotin and pantothenic acid oversupplementation to conditional SLC5A6 KO mice prevents the development of intestinal mucosal abnormalities and growth defects. Am. J. Physiol. Cell Physiol. 2018, 315, C73-C79. [CrossRef]

28. Said, H.M. Intestinal absorption of water-soluble vitamins in health and disease. Biochem. J. 2011, 437, 357-372. [CrossRef]

29. Trumbo, P. Pantothenic Acid. In Modern Nutrition in Health and Disease; Ross, A., Caballero, B., Cousins, R., Eds.; Lippincott Williams \& Wilkins: Baltimore, MD, USA, 2014; pp. 351-357.

30. Lopez Martinez, D.; Tsuchiya, Y.; Gout, I. Coenzyme A biosynthetic machinery in mammalian cells. Biochem. Soc. Trans. 2014, 42, 1112-1117. [CrossRef]

31. Leonardi, R.; Zhang, Y.M.; Rock, C.O.; Jackowski, S. Coenzyme A: Back in action. Prog. Lipid Res. 2005, 44, 125-153. [CrossRef]

32. Zhang, Y.M.; Rock, C.O.; Jackowski, S. Feedback regulation of murine pantothenate kinase 3 by coenzyme A and coenzyme A thioesters. J. Biol. Chem. 2005, 280, 32594-32601. [CrossRef]

33. Dansie, L.E.; Reeves, S.; Miller, K.; Zano, S.P.; Frank, M.; Pate, C.; Wang, J.; Jackowski, S. Physiological roles of the pantothenate kinases. Biochem. Soc. Trans. 2014, 42, 1033-1036. [CrossRef]

34. Alfonso-Pecchio, A.; Garcia, M.; Leonardi, R.; Jackowski, S. Compartmentalization of Mammalian Pantothenate Kinases. PLoS ONE 2012, 7, 49509. [CrossRef] 
35. Zhyvoloup, A.; Nemazanyy, I.; Panasyuk, G.; Valovka, T.; Fenton, T.; Rebholz, H.; Wang, M.L.; Foxon, R.; Lyzogubov, V.; Usenko, V.; et al. Subcellular Localization and Regulation of Coenzyme A Synthase. J. Biol. Chem. 2003, 278, 50316-50321. [CrossRef]

36. Gout, I. Coenzyme A, protein CoAlation and redox regulation in mammalian cells. Biochem. Soc. Trans. 2018, 46, 721-728. [CrossRef]

37. Trams, E.G.; Fales, H.A.; Gal, A.E. S-Palmityl pantetheine as an intermediate in the metabolism of palmityl coenzyme A by rat liver plasma membrane preparations. Biochem. Biophys. Res. Commun. 1968, 31, 973-976. [CrossRef]

38. Franklin, J.E.; Trams, E.G. Metabolism of coenzyme A and related nucleotides by liver plasma membranes. BBA Gen. Subj. 1971, 230, 105-116. [CrossRef]

39. Skrede, S. The Degradation of CoA: Subcellular Localization and Kinetic Properties of CoA-and Dephospho-CoA Pyrophosphatase. Eur. J. Biochem. 1973, 38, 401-407. [CrossRef]

40. Lee, S.Y.; Müller, C.E. Nucleotide pyrophosphatase/phosphodiesterase 1 (NPP1) and its inhibitors. Medchemcomm 2017, 8, 823-840. [CrossRef]

41. Goding, J.W.; Grobben, B.; Slegers, H. Physiological and pathophysiological functions of the ecto-nucleotide pyrophosphatase/phosphodiesterase family. Biochim. Biophys. Acta Mol. Basis Dis. 2003, 1638, 1-19. [CrossRef]

42. Wittwer, C.T.; Burkhard, D.; Ririe, K.; Rasmussen, R.; Brown, J.; Wyse, B.W.; Hansen, G.R. Purification and properties of a pantetheine-hydrolyzing enzyme from pig kidney. J. Biol. Chem. 1983, 258, 9733-9738.

43. Granjeaud, S.; Naquet, P.; Galland, F. An ESTs description of the new Vanin gene family conserved from fly to human. Immunogenetics 1999, 49, 964-972. [CrossRef]

44. Martin, F.; Malergue, F.; Pitari, G.; Philippe, J.M.; Philips, S.; Chabret, C.; Granjeaud, S.; Mattei, M.G.; Mungall, A.J.; Naquet, P.; et al. Vanin genes are clustered (human 6q22-24 and mouse 10A2B1) and encode isoforms of pantetheinase ectoenzymes. Immunogenetics 2001, 53, 296-306. [CrossRef]

45. Maras, B.; Barra, D.; Duprè, S.; Pitari, G. Is pantetheinase the actual identity of mouse and human vanin-1 proteins? FEBS Lett. 1999, 461, 149-152. [CrossRef]

46. Berruyer, C.; Pouyet, L.; Millet, V.; Martin, F.M.; LeGoffic, A.; Canonici, A.; Garcia, S.; Bagnis, C.; Naquet, P.; Galland, F. Vanin-1 licenses inflammatory mediator production by gut epithelial cells and controls colitis by antagonizing peroxisome proliferator-activated receptor $\gamma$ activity. J. Exp. Med. 2006, 203, 2817-2827. [CrossRef] [PubMed]

47. Pitari, G.; Malergue, F.; Martin, F.; Philippe, J.M.; Massucci, M.T.; Chabret, C.; Maras, B.; Duprè, S.; Naquet, P.; Galland, F. Pantetheinase activity of membrane-bound Vanin-1: Lack of free cysteamine in tissues of Vanin-1 deficient mice. FEBS Lett. 2000, 483, 149-154. [CrossRef]

48. Nitto, T.; Inoue, T.; Node, K. Alternative spliced variants in the pantetheinase family of genes expressed in human neutrophils. Gene 2008, 426, 57-64. [CrossRef] [PubMed]

49. Rommelaere, S.; Millet, V.; Rihet, P.; Atwell, S.; Helfer, E.; Chasson, L.; Beaumont, C.; Chimini, G.; Sambo, M.D.R.; Viallat, A.; et al. Serum Pantetheinase/Vanin Levels regulate erythrocyte homeostasis and severity of malaria. Am. J. Pathol. 2015, 185, 3039-3052. [CrossRef] [PubMed]

50. Kerr, E.W.; Shumar, S.A.; Leonardi, R. Nudt8 is a novel CoA diphosphohydrolase that resides in the mitochondria. FEBS Lett. 2019, 593, 1133-1143. [CrossRef] [PubMed]

51. Reilly, S.J.; Tillander, V.; Ofman, R.; Alexson, S.E.H.; Hunt, M.C. The nudix hydrolase 7 is an acyl-CoA diphosphatase involved in regulating peroxisomal coenzyme A homeostasis. J. Biochem. 2008, 144, 655-663. [CrossRef]

52. Shumar, S.A.; Kerr, E.W.; Geldenhuys, W.J.; Montgomery, G.E.; Fagone, P.; Thirawatananond, P.; Saavedra, H.; Gabelli, S.B.; Leonardi, R. Nudt19 is a renal CoA diphosphohydrolase with biochemical and regulatory properties that are distinct from the hepatic Nudt7 isoform. J. Biol. Chem. 2018, 293, 4134-4148. [CrossRef]

53. Guranowski, A. Fluoride is a strong and specific inhibitor of (asymmetrical) Ap4A hydrolases. FEBS Lett. 1990, 262, 205-208. [CrossRef]

54. Ofman, R.; Speijer, D.; Leen, R.; Wanders, R.J.A. Proteomic analysis of mouse kidney peroxisomes: Identification of RP2p as a peroxisomal nudix hydrolase with acyl-CoA diphosphatase activity. Biochem. J. 2006, 393, 537-543. [CrossRef]

55. Hunt, M.C.; Tillander, V.; Alexson, S.E.H. Regulation of peroxisomal lipid metabolism: The role of acyl-CoA and coenzyme A metabolizing enzymes. Biochimie 2014, 98, 45-55. [CrossRef] 
56. Antonenkov, V.D.; Hiltunen, J.K. Transfer of metabolites across the peroxisomal membrane. Biochim. Biophys. Acta Mol. Basis Dis. 2012, 1822, 1374-1386. [CrossRef] [PubMed]

57. Gieselmann, V.; Hasilik, A.; Figura, K. Von Tartrate-inhibitable acid phosphatase purification from placenta, characterization and subcellular distribution in fibroblasts. Hoppe. Seylers. Z. Physiol. Chem. 1984, 365, 651-660. [CrossRef] [PubMed]

58. Verkruyse, L.A.; Hofmann, S.L. Lysosomal targeting of palmitoyl-protein thioesterase. J. Biol. Chem. 1996, 271, 15831-15836. [CrossRef] [PubMed]

59. Camp, L.; Verkruyse, L.A.; Afendis, S.J.; Slaughter, C.; Hofmann, S. Molecular cloning and expression of palmitoyl-protein thioesterase. J. Biol. Chem. 1994, 269, 23212-23219. [PubMed]

60. Calero, G.; Gupta, P.; Nonato, M.C.; Tandel, S.; Biehl, E.R.; Hofmann, S.L.; Clardy, J. The crystal structure of palmitoyl protein thioesterase-2 (PPT2) reveals the basis for divergent substrate specificities of the two lysosomal thioesterases, PPT1 and PPT2. J. Biol. Chem. 2003, 278, 37957-37964. [CrossRef] [PubMed]

61. Chapel, A.; Kieffer-Jaquinod, S.; Sagné, C.; Verdon, Q.; Ivaldi, C.; Mellal, M.; Thirion, J.; Jadot, M.; Bruley, C.; Garin, J.; et al. An extended proteome map of the lysosomal membrane reveals novel potential transporters. Mol. Cell. Proteom. 2013, 12, 1572-1588. [CrossRef]

62. Frank, M.W.; Subramanian, C.; Rock, C.O.; Jackowski, S. Quantification of Coenzyme A in Cells and Tissues. J. Vis. Exp. 2019, 151. [CrossRef]

63. Robishaw, J.; Neely, J.R. Coenzyme A metabolism. Am. J. Physiol. Endocrinol. Metab. 1985, 11. [CrossRef]

64. Shurubor, Y.I.; D’Aurelio, M.; Clark-Matott, J.; Isakova, E.P.; Deryabina, Y.I.; Beal, M.F.; Cooper, A.J.L.; Krasnikov, B.F. Determination of Coenzyme A and Acetyl-Coenzyme A in Biological Samples Using HPLC with UV Detection. Molecules 2017, 22, 1388. [CrossRef]

65. Tahiliani, A.G.; Beinlich, C.J. Pantothenic Acid in Health and Disease. Vitam. Horm. 1991, 46, 165-228.

66. Tubbs, P.K.; Garland, P.B. Variations in tissue contents of coenzyme A thio esters and possible metabolic implications. Biochem. J. 1964, 93, 550-557. [CrossRef] [PubMed]

67. Zhang, Y.M.; Chohnan, S.; Virga, K.G.; Stevens, R.D.; Ilkayeva, O.R.; Wenner, B.R.; Bain, J.R.; Newgard, C.B.; Lee, R.E.; Rock, C.O.; et al. Chemical Knockout of Pantothenate Kinase Reveals the Metabolic and Genetic Program Responsible for Hepatic Coenzyme A Homeostasis. Chem. Biol. 2007, 14, 291-302. [CrossRef] [PubMed]

68. Rapp, G.W. Some systemic effects of malignant tumors. I. Co-enzyme A levels. Cancer 1973, 31, 357-360. [CrossRef]

69. Peng, Y.; Puglielli, L. Ne-lysine acetylation in the lumen of the endoplasmic reticulum: A way to regulate autophagy and maintain protein homeostasis in the secretory pathway. Autophagy 2016, 12, 1051-1052. [CrossRef]

70. Costantini, C.; Ko, M.H.; Jonas, M.C.; Puglielli, L. A reversible form of lysine acetylation in the ER and Golgi lumen controls the molecular stabilization of BACE1. Biochem. J. 2007, 407, 383-395. [CrossRef]

71. Hunt, M.C.; Alexson, S.E.H. The role Acyl-CoA thioesterases play in mediating intracellular lipid metabolism. Prog. Lipid Res. 2002, 41, 99-130. [CrossRef]

72. Fiermonte, G.; Paradies, E.; Todisco, S.; Marobbio, C.M.T.; Palmieri, F. A novel member of solute carrier family 25 (SLC25A42) is a transporter of coenzyme A and adenosine $3^{\prime}, 5^{\prime}$-diphosphate in human mitochondria. J. Biol. Chem. 2009, 284, 18152-18159. [CrossRef]

73. Kemp, S.; Theodoulou, F.L.; Wanders, R.J.A. Mammalian peroxisomal ABC transporters: From endogenous substrates to pathology and clinical significance. Br. J. Pharmacol. 2011, 164, 1753-1766. [CrossRef]

74. Baker, A.; Carrier, D.J.; Schaedler, T.; Waterham, H.R.; Van Roermund, C.W.; Theodoulou, F.L. Peroxisomal ABC transporters: Functions and mechanism. Biochem. Soc. Trans. 2015, 43, 959-965. [CrossRef]

75. Agrimi, G.; Russo, A.; Scarcia, P.; Palmieri, F. The human gene SLC25A17 encodes a peroxisomal transporter of coenzyme A, FAD and NAD+. Biochem. J. 2012, 443, 241-247. [CrossRef]

76. Jonas, M.C.; Pehar, M.; Puglielli, L. AT-1 is the ER membrane acetyl-CoA transporter and is essential for cell viability. J. Cell Sci. 2010, 123, 3378-3388. [CrossRef] [PubMed]

77. Beld, J.; Sonnenschein, E.C.; Vickery, C.R.; Noel, J.P.; Burkart, M.D. The phosphopantetheinyl transferases: Catalysis of a post-translational modification crucial for life. Nat. Prod. Rep. 2014, 31, 61-108. [CrossRef] [PubMed] 
78. Lambrechts, R.A.; Schepers, H.; Yu, Y.; van der Zwaag, M.; Autio, K.J.; Vieira-Lara, M.A.; Bakker, B.M.; Tijssen, M.A.; Hayflick, S.J.; Grzeschik, N.A.; et al. CoA-dependent activation of mitochondrial acyl carrier protein links four neurodegenerative diseases. EMBO Mol. Med. 2019, 11, e10488. [CrossRef] [PubMed]

79. Drazic, A.; Myklebust, L.M.; Ree, R.; Arnesen, T. The world of protein acetylation. Biochim. Biophys. Acta Proteins Proteomics 2016, 1864, 1372-1401. [CrossRef]

80. Wang, Y.; Chen, Y.; Chen, Q.; Zhang, X.; Wang, H.; Wang, Z.; Wang, J.; Tian, C. The role of acetylation sites in the regulation of p53 activity. Mol. Biol. Rep. 2020, 47, 381-391. [CrossRef]

81. Popov, D. Protein S-glutathionylation: From current basics to targeted modifications. Arch. Physiol. Biochem. 2014, 120, 123-130. [CrossRef]

82. Huth, W.; Pauli, C.; Möller, U. Immunochemical detection of CoA-modified mitochondrial matrix proteins. Biochem. J. 1996, 320, 451-457. [CrossRef]

83. Ley, S.C.; De Carvalho, L.P.S. Protein CoAlation: A redox-linked post-translational modification. Biochem. J. 2017, 474, 2897-2899. [CrossRef]

84. Van Laer, K.; Hamilton, C.J.; Messens, J. Low-molecular-weight thiols in thiol-disulfide exchange. Antioxidants Redox Signal. 2013, 18, 1642-1653. [CrossRef]

85. Jakubowski, H. Homocysteine modification in protein structure/function and human disease. Physiol. Rev. 2019, 99, 555-604. [CrossRef]

86. Tsuchiya, Y.; Zhyvoloup, A.; Baković, J.; Thomas, N.; Yu, B.Y.K.; Das, S.; Orengo, C.; Newell, C.; Ward, J.; Saladino, G.; et al. Protein CoAlation and antioxidant function of coenzyme A in prokaryotic cells. Biochem. J. 2018, 475, 1909-1937. [CrossRef] [PubMed]

87. Tsuchiya, Y.; Peak-Chew, S.Y.; Newell, C.; Miller-Aidoo, S.; Mangal, S.; Zhyvoloup, A.; Baković, J.; Malanchuk, O.; Pereira, G.C.; Kotiadis, V.; et al. Protein CoAlation: A redox-regulated protein modification by coenzyme A in mammalian cells. Biochem. J. 2017, 474, 2489-2508. [CrossRef] [PubMed]

88. Huth, W.; Arvand, M.; Moller, U. Identification of [1-14C]pantothenic-acid-mediated modified mitochondrial proteins. Eur. J. Biochem. 1988, 172, 607-614. [CrossRef] [PubMed]

89. Schwerdt, G.; Huth, W. Turnover and transformation of mitochondrial acetyl-CoA acetyltransterase into CoA-modified forms. Biochem. J. 1993, 292, 915-919. [CrossRef] [PubMed]

90. Quandt, L.; Huth, W. Modulation of rat-liver mitochondrial acetyl-CoA acetyltransferase activity by a reversible chemical modification with coenzyme A. Biochim. Biophys. Acta (BBA)/Protein Struct. Mol. 1984, 784, 168-176. [CrossRef]

91. Baković, J.; Yu, B.Y.K.; Silva, D.; Chew, S.P.; Kim, S.; Ahn, S.H.; Palmer, L.; Aloum, L.; Stanzani, G.; Malanchuk, O.; et al. A key metabolic integrator, coenzyme A, modulates the activity of peroxiredoxin 5 via covalent modification. Mol. Cell. Biochem. 2019, 461, 91-102. [CrossRef]

92. Tsuchiya, Y.; Byrne, D.P.; Burgess, S.G.; Bormann, J.; Baković, J.; Huang, Y.; Zhyvoloup, A.; Yu, B.Y.K.; Peak-Chew, S.; Tran, T.; et al. Covalent Aurora A regulation by the metabolic integrator coenzyme A. Redox Biol. 2020, 28, 101318. [CrossRef]

93. Di Meo, I.; Carecchio, M.; Tiranti, V. Inborn errors of coenzyme a metabolism and neurodegeneration. J. Inherit. Metab. Dis. 2019, 42, 49-56. [CrossRef]

94. Jung, S.; Kim, M.K.; Choi, B.Y. The long-term relationship between dietary pantothenic acid (vitamin B5) intake and C-reactive protein concentration in adults aged 40 years and older. Nutr. Metab. Cardiovasc. Dis. 2017, 27, 806-816. [CrossRef]

95. Bokhari, M.R.; Zulfiqar, H.; Bokhari, S.R.A. Hallervorden Spatz Disease (Pantothenate Kinase-Associated Neurodegeneration, PKAN)-StatPearls-NCBI Bookshelf; StatPearls Publishing: Treasure Island, FL, USA, 2020.

96. Subramanian, C.; Yao, J.; Frank, M.W.; Rock, C.O.; Jackowski, S. A pantothenate kinase-deficient mouse model reveals a gene expression program associated with brain coenzyme a reduction. Biochim. Biophys. Acta Mol. Basis Dis. 2020, 1866, 165663. [CrossRef]

97. Venco, P.; Dusi, S.; Valletta, L.; Tiranti, V. Alteration of the coenzyme A biosynthetic pathway in neurodegeneration with brain iron accumulation syndromes. Biochem. Soc. Trans. 2014, 42, 1069-1074. [CrossRef] [PubMed]

98. Orellana, D.I.; Santambrogio, P.; Rubio, A.; Yekhlef, L.; Cancellieri, C.; Dusi, S.; Giannelli, S.G.; Venco, P.; Mazzara, P.G.; Cozzi, A.; et al. Coenzyme A corrects pathological defects in human neurons of PANK 2-associated neurodegeneration. EMBO Mol. Med. 2016, 8, 1197-1211. [CrossRef] [PubMed] 
99. Sharma, L.K.; Subramanian, C.; Yun, M.K.; Frank, M.W.; White, S.W.; Rock, C.O.; Lee, R.E.; Jackowski, S. A therapeutic approach to pantothenate kinase associated neurodegeneration. Nat. Commun. 2018, 9, 1-15. [CrossRef] [PubMed]

100. Van Dijk, T.; Ferdinandusse, S.; Ruiter, J.P.N.; Alders, M.; Mathijssen, I.B.; Parboosingh, J.S.; Innes, A.M.; Meijers-Heijboer, H.; Poll-The, B.T.; Bernier, F.P.; et al. Biallelic loss of function variants in COASY cause prenatal onset pontocerebellar hypoplasia, microcephaly, and arthrogryposis. Eur. J. Hum. Genet. 2018, 26, 1752-1758. [CrossRef] [PubMed]

101. Lee, J.H.; Gurney, S.; Pang, D.; Temkin, A.; Park, N.; Janicki, S.C.; Zigman, W.B.; Silverman, W.; Tycko, B.; Schupf, N. Polymorphisms in HSD17B1: Early onset and increased risk of Alzheimer's disease in women with down syndrome. Curr. Gerontol. Geriatr. Res. 2012, 2012. [CrossRef]

102. Kobayashi, N.; Shinagawa, S.; Nagata, T.; Shimada, K.; Shibata, N.; Ohnuma, T.; Kasanuki, K.; Arai, H.; Yamada, H.; Nakayama, K.; et al. Usefulness of DNA Methylation Levels in COASY and SPINT1 Gene Promoter Regions as Biomarkers in Diagnosis of Alzheimer's Disease and Amnestic Mild Cognitive Impairment. PLoS ONE 2016, 11, e0168816. [CrossRef]

103. Bartus, R.T.; Dean, R.L.; Beer, B.; Lippa, A.S. The cholinergic hypothesis of geriatric memory dysfunction. Science 1982, 217, 408-417. [CrossRef]

104. Patassini, S.; Begley, P.; Xu, J.; Church, S.J.; Reid, S.J.; Kim, E.H.; Curtis, M.A.; Dragunow, M.; Waldvogel, H.J.; Snell, R.G.; et al. Metabolite mapping reveals severe widespread perturbation of multiple metabolic processes in Huntington's disease human brain. Biochim. Biophys. Acta Mol. Basis Dis. 2016, 1862, 1650-1662. [CrossRef]

105. Iuso, A.; Alhaddad, B.; Weigel, C.; Kotzaeridou, U.; Mastantuono, E.; Schwarzmayr, T.; Graf, E.; Terrile, C.; Prokisch, H.; Strom, T.M.; et al. A homozygous splice site mutation in SLC25A42, encoding the mitochondrial transporter of coenzyme a, causes metabolic crises and epileptic encephalopathy. JIMD Rep. 2019, 44, 1-7.

106. Almannai, M.; Alasmari, A.; Alqasmi, A.; Faqeih, E.; Al Mutairi, F.; Alotaibi, M.; Samman, M.M.; Eyaid, W.; Aljadhai, Y.I.; Shamseldin, H.E.; et al. Expanding the phenotype of SLC25A42-associated mitochondrial encephalomyopathy. Clin. Genet. 2018, 93, 1097-1102. [CrossRef]

107. De Berardinis, R.J.; Chandel, N.S. Fundamentals of cancer metabolism. Sci. Adv. 2016, 2, e1600200. [CrossRef] [PubMed]

108. Cairns, R. The current state of cancer metabolism. Nat. Rev. Cancer 2016, 16, 613-614. [CrossRef]

109. Dubuis, S.; Ortmayr, K.; Zampieri, M. A framework for large-scale metabolome drug profiling links coenzyme A metabolism to the toxicity of anti-cancer drug dichloroacetate. Commun. Biol. 2018, 1, 101. [CrossRef] [PubMed]

110. Kharabsheh, H.A.; Scott, J.E. CoAsy knockdown in TNBC cell lines resulted in no overt effect on cell proliferation in vitro. Biochem. Biophys. Res. Commun. 2020, 530, 136-141. [CrossRef] [PubMed]

111. Yan, M.; Wang, C.; He, B.; Yang, M.; Tong, M.; Long, Z.; Liu, B.; Peng, F.; Xu, L.; Zhang, Y.; et al. Aurora-A Kinase: A Potent Oncogene and Target for Cancer Therapy. Med. Res. Rev. 2016, 36, 1036-1079. [CrossRef]

112. Liu, Y.; Cheng, Z.; Li, Q.; Pang, Y.; Cui, L.; Qian, T.; Quan, L.; Dai, Y.; Jiao, Y.; Zhang, Z.; et al. Prognostic significance of the PANK family expression in acute myeloid leukemia. Ann. Transl. Med. 2019, 7, 261. [CrossRef]

113. Xiang, R.L.; Yang, Y.L.; Zuo, J.; Xiao, X.H.; Chang, Y.S.; De Fang, F. PanK4 inhibits pancreatic $\beta$-cell apoptosis by decreasing the transcriptional level of pro-caspase-9. Cell Res. 2007, 17, 966-968. [CrossRef]

114. Izzi, V.; Lakkala, J.; Devarajan, R.; Savolainen, E.-R.; Koistinen, P.; Heljasvaara, R.; Pihlajaniemi, T. Vanin 1 (VNN1) levels predict poor outcome in acute myeloid leukemia. Am. J. Hematol. 2018, 93, E4-E7. [CrossRef]

115. Nagai, M.A.; da Rós, N.; Neto, M.M.; de Faria Junior, S.R.; Brentani, M.M.; Hirata, R.; Neves, E.J. Gene expression profiles in breast tumors regarding the presence or absence of estrogen and progesterone receptors. Int. J. Cancer 2004, 111, 892-899. [CrossRef]

116. Williams, C.; Edvardsson, K.; Lewandowski, S.A.; Ström, A.; Gustafsson, J.Å. A genome-wide study of the repressive effects of estrogen receptor beta on estrogen receptor alpha signaling in breast cancer cells. Oncogene 2008, 27, 1019-1032. [CrossRef]

117. Lapin, V.; Shirdel, E.A.; Wei, X.; Mason, J.M.; Jurisica, I.; Mak, T.W. Kinome-wide screening of HER2+ breast cancer cells for molecules that mediate cell proliferation or sensitize cells to trastuzumab therapy. Oncogenesis 2014, 3, e133. [CrossRef] [PubMed] 
118. Gast, K.C.; Cathcart-Rake, E.J.; Norman, A.D.; Eshraghi, L.; Obidegwu, N.; Nichols, H.B.; Rosenberg, S.; $\mathrm{Su}$, H.I.; Stewart, E.A.; Couch, F.J.; et al. Regimen-specific rates of chemotherapy-related amenorrhea in breast cancer survivors. JNCI Cancer Spectr. 2019, 3. [CrossRef]

119. Findeklee, S.; Lotz, L.; Heusinger, K.; Hoffmann, I.; Dittrich, R.; Beckmann, M.W. Fertility Protection in Female Oncology Patients: How Should Patients Be Counseled? Geburtshilfe Frauenheilkd. 2015, 75, 1243-1249. [CrossRef] [PubMed]

120. Ruddy, K.J.; Schaid, D.J.; Partridge, A.H.; Larson, N.B.; Batzler, A.; Häberle, L.; Dittrich, R.; Widschwendter, P.; Fink, V.; Bauer, E.; et al. Genetic predictors of chemotherapy-related amenorrhea in women with breast cancer. Fertil. Steril. 2019, 112, 731-739.e1. [CrossRef]

121. Czumaj, A.; Zabielska, J.; Pakiet, A.; Mika, A.; Rostkowska, O.; Makarewicz, W.; Kobiela, J.; Sledzinski, T.; Stelmanska, E. In vivo effectiveness of orlistat in the suppression of human colorectal cancer cell proliferation. Anticancer Res. 2019, 39, 3815-3822. [CrossRef] [PubMed]

122. Ferrandon, S.; Devecchio, J.; Duraes, L.; Chouhan, H.; Karagkounis, G.; Davenport, J.; Orloff, M.; Liska, D.; Kalady, M.F. CoA Synthase (COASY) Mediates Radiation Resistance via PI3K Signaling in Rectal Cancer. Cancer Res. 2020, 80, 334-346. [CrossRef] [PubMed]

123. Ferron, S.; Kalady, M.F. Identifying new targets for rectal cancer treatment. Oncoscience 2020, 7, 36-37. [CrossRef]

124. Chai, C.Y.; Zhang, Y.; Song, J.; Lin, S.C.; Sun, S.; Chang, I.W. VNN1 overexpression is associated with poor response to preoperative chemoradiotherapy and adverse prognosis in patients with rectal cancers. Am. J. Transl. Res. 2016, 8, 4455-4463.

125. Zhang, L.; Li, L.; Gao, G.; Wei, G.; Zheng, Y.; Wang, C.; Gao, N.; Zhao, Y.; Deng, J.; Chen, H.; et al. Elevation of GPRC5A expression in colorectal cancer promotes tumor progression through VNN-1 induced oxidative stress. Int. J. Cancer 2017, 140, 2734-2747. [CrossRef]

126. Marshall, K.W.; Mohr, S.; El Khettabi, F.; Nossova, N.; Chao, S.; Bao, W.; Ma, J.; Li, X.J.; Liew, C.C. A blood-based biomarker panel for stratifying current risk for colorectal cancer. Int. J. Cancer 2010, 126, 1177-1186. [CrossRef]

127. Yip, K.T.; Das, P.K.; Suria, D.; Lim, C.R.; Ng, G.H.; Liew, C.C. A case-controlled validation study of a blood-based seven-gene biomarker panel for colorectal cancer in Malaysia. J. Exp. Clin. Cancer Res. 2010, 29, 128. [CrossRef] [PubMed]

128. Sharma, P.; Saraya, A.; Gupta, P.; Sharma, R. Decreased levels of circulating and tissue miR-107 in human esophageal cancer. Biomarkers 2013, 18, 322-330. [CrossRef] [PubMed]

129. Zhong, K.Z.; Chen, W.W.; Hu, X.Y.; Jiang, A.L.; Zhao, J. Clinicopathological and prognostic significance of microRNA-107 in human non small cell lung cancer. Int. J. Clin. Exp. Pathol. 2014, 7, 4545-4551. [PubMed]

130. Roldo, C.; Missiaglia, E.; Hagan, J.P.; Falconi, M.; Capelli, P.; Bersani, S.; Calin, G.A.; Volinia, S.; Liu, C.G.; Scarpa, A.; et al. MicroRNA expression abnormalities in pancreatic endocrine and acinar tumors are associated with distinctive pathologic features and clinical behavior. J. Clin. Oncol. 2006, 24, 4677-4684. [CrossRef] [PubMed]

131. Li, X.Y.; Luo, Q.F.; Wei, C.K.; Li, D.F.; Li, J.; Fang, L. MiRNA-107 inhibits proliferation and migration by targeting CDK8 in breast cancer. Int. J. Clin. Exp. Med. 2014, 7, 32-40. [PubMed]

132. Zhang, Z.; Zhang, L.; Yin, Z.Y.; Fan, X.L.; Hu, B.; Wang, L.Q.; Zhang, D. miR-107 regulates cisplatin chemosensitivity of A549 non small cell lung cancer cell line by targeting cyclin dependent kinase 8 . Int. J. Clin. Exp. Pathol. 2014, 7, 7236-7241. [PubMed]

133. Roediger, W.E.W. Causation of human ulcerative colitis: A lead from an animal model that mirrors human disease. JGH Open 2019, 3, 277-280. [CrossRef]

134. Wintrobe, M.M.; Follis, R.H.J.; Alcayaga, R.; Paulson, M.; Humphreys, S. Pantothenic acid deficiency in swine with particular reference to the effects on growth and on the alimentary tract. Bull. Johns Hopkins Hosp. 1943, 73, 313-341.

135. Gensollen, T.; Bourges, C.; Rihet, P.; Rostan, A.; Millet, V.; Noguchi, T.; Bourdon, V.; Sobol, H.; Dubuquoy, L.; Bertin, B.; et al. Functional polymorphisms in the regulatory regions of the VNN1 gene are associated with susceptibility to inflammatory bowel diseases. Inflamm. Bowel Dis. 2013, 19, 2315-2325. [CrossRef]

136. Lewis, G.D.; Farrell, L.; Wood, M.J.; Martinovic, M.; Arany, Z.; Rowe, G.C.; Souza, A.; Cheng, S.; McCabe, E.L.; Yang, E.; et al. Metabolic signatures of exercise in human plasma. Sci. Transl. Med. 2010, 2, 33ra37. [CrossRef] 
137. Corbin, D.R.; Rehg, J.E.; Shepherd, D.L.; Stoilov, P.; Percifield, R.J.; Horner, L.; Frase, S.; Zhang, Y.M.; Rock, C.O.; Hollander, J.M.; et al. Excess coenzyme A reduces skeletal muscle performance and strength in mice overexpressing human PANK2. Mol. Genet. Metab. 2017, 120, 350-362. [CrossRef] [PubMed]

138. Ostman-Smith, I.; Brown, G.; Johnson, A.; Land, J.M.; Johnson, L.A. Dilated cardiomyopathy due to type II X-linked 3-methylglutaconic aciduria: Successful treatment with. pantothenic acid. Heart 1994, 72, 349-353. [CrossRef]

139. Rugolotto, S.; Prioli, M.D.; Toniolo, D.; Pellegrino, P.A.; Catuogno, S.; Burlina, A.B. Long-term treatment of Barth syndrome with pantothenic acid: A retrospective study. Mol. Genet. Metab. 2003, 80, 408-411. [CrossRef] [PubMed]

140. Brohn, F.H.; Trager, W. Coenzyme A Requirement of Malaria Parasites: Enzymes of Coenzyme A Biosynthesis in Normal Duck Erythrocytes and Erythrocytes Infected with Plasmodium lophurae* (intracellular parasitism/host parasite relations). Proc. Natl. Acad. Sci. USA 1975, 72, 2456-2458. [CrossRef] [PubMed]

141. Saliba, K.J.; Horner, H.A.; Kirk, K. Transport and metabolism of the essential vitamin pantothenic acid in human erythrocytes infected with the malaria parasite Plasmodium falciparum. J. Biol. Chem. 1998, 273, 10190-10195. [CrossRef]

142. Saliba, K.J.; Ferru, I.; Kirk, K. Provitamin B5 (Pantothenol) inhibits growth of the intraerythrocytic malaria parasite. Antimicrob. Agents Chemother. 2005, 49, 632-637. [CrossRef]

143. Saliba, K.J.; Kirk, K. H ${ }^{+}$-coupled Pantothenate Transport in the Intracellular Malaria Parasite. J. Biol. Chem. 2001, 276, 18115-18121. [CrossRef]

144. Spry, C.; Macuamule, C.; Lin, Z.; Virga, K.G.; Lee, R.E.; Strauss, E.; Saliba, K.J. Pantothenamides Are Potent, On-Target Inhibitors of Plasmodium falciparum Growth When Serum Pantetheinase Is Inactivated. PLoS ONE 2013, 8, e54974. [CrossRef]

145. Tjhin, E.T.; Spry, C.; Sewell, A.L.; Hoegl, A.; Barnard, L.; Sexton, A.E.; Siddiqui, G.; Howieson, V.M.; Maier, A.G.; Creek, D.J.; et al. Mutations in the pantothenate kinase of Plasmodium falciparum confer diverse sensitivity profiles to antiplasmodial pantothenate analogues. PLoS Pathog. 2018, 14, e1006918. [CrossRef]

146. Spry, C.; van Schalkwyk, D.A.; Strauss, E.; Saliba, K.J. Pantothenate Utilization by Plasmodium as a Target for Antimalarial Chemotherapy. Infect. Disord. Drug Targets 2012, 10, 200-216. [CrossRef]

147. Min-Oo, G.; Fortin, A.; Pitari, G.; Tam, M.; Stevenson, M.M.; Gros, P. Complex genetic control of susceptibility to malaria: Positional cloning of the Char9 locus. J. Exp. Med. 2007, 204, 511-524. [CrossRef] [PubMed]

148. Min-Oo, G.; Ayi, K.; Bongfen, S.E.; Tam, M.; Radovanovic, I.; Gauthier, S.; Santiago, H.; Rothfuchs, A.G.; Roffê, E.; Sher, A.; et al. Cysteamine, the natural metabolite of pantetheinase, shows specific activity against Plasmodium. Exp. Parasitol. 2010, 125, 315-324. [CrossRef] [PubMed]

149. Naquet, P.; Pitari, G.; Duprè, S.; Galland, F. Role of the Vnn1 pantetheinase in tissue tolerance to stress. Biochem. Soc. Trans. 2014, 42, 1094-1100. [CrossRef] [PubMed]

150. Martin, F.; Penet, M.-F.; Malergue, F.; Lepidi, H.; Dessein, A.; Galland, F.; de Reggi, M.; Naquet, P.; Gharib, B. Vanin-1-/- mice show decreased NSAID- and Schistosoma-induced intestinal inflammation associated with higher glutathione stores. J. Clin. Investig. 2004, 113, 591-597. [CrossRef] [PubMed]

151. Meghari, S.; Berruyer, C.; Lepidi, H.; Galland, F.; Naquet, P.; Mege, J.L. Vanin-1 controls granuloma formation and macrophage polarization in Coxiella burnetii infection. Eur. J. Immunol. 2007, 37, 24-32. [CrossRef]

152. Clifton, G.; Bryant, S.R.; Skinner, C.G. N1-(substituted) pantothenamides, antimetabolites of pantothenic acid. Arch. Biochem. Biophys. 1970, 137, 523-528. [CrossRef]

153. de Villiers, M.; Barnard, L.; Koekemoer, L.; Snoep, J.L.; Strauss, E. Variation in pantothenate kinase type determines the pantothenamide mode of action and impacts on coenzyme A salvage biosynthesis. FEBS J. 2014, 281, 4731-4753. [CrossRef]

154. Jansen, P.A.M.; van der Krieken, D.A.; Botman, P.N.M.; Blaauw, R.H.; Cavina, L.; Raaijmakers, E.M.; de Heuvel, E.; Sandrock, J.; Pennings, L.J.; Hermkens, P.H.H.; et al. Stable pantothenamide bioisosteres: Novel antibiotics for Gram-positive bacteria. J. Antibiot. 2019, 72, 682-692. [CrossRef]

155. Hoegl, A.; Darabi, H.; Tran, E.; Awuah, E.; Kerdo, E.S.C.; Habib, E.; Saliba, K.J.; Auclair, K. Stereochemical modification of geminal dialkyl substituents on pantothenamides alters antimicrobial activity. Bioorganic Med. Chem. Lett. 2014, 24, 3274-3277. [CrossRef]

156. Maršavelski, A. A novel antimicrobial target-Expanded and revisited mode of action of pantothenamides. RSC Adv. 2016, 6, 44888-44895. [CrossRef] 
157. Hughes, S.J.; Barnard, L.; Mottaghi, K.; Tempel, W.; Antoshchenko, T.; Hong, B.S.; Allali-Hassani, A.; Smil, D.; Vedadi, M.; Strauss, E.; et al. Discovery of potent pantothenamide inhibitors of staphylococcus Aureus Pantothenate Kinase through a minimal SAR Study: Inhibition Is Due to Trapping of the Product. ACS Infect. Dis. 2016, 2, 627-641. [CrossRef] [PubMed]

158. Barnard, L.; Mostert, K.J.; Van Otterlo, W.A.L.; Strauss, E. Developing Pantetheinase-Resistant Pantothenamide Antibacterials: Structural Modification Impacts on PanK Interaction and Mode of Action. ACS Infect. Dis. 2018, 4, 736-743. [CrossRef] [PubMed]

159. Jansen, P.A.M.; Hermkens, P.H.H.; Zeeuwen, P.L.J.M.; Botman, P.N.M.; Blaauw, R.H.; Burghout, P.; Van Galen, P.M.; Mouton, J.W.; Rutjes, F.P.J.T.; Schalkwijk, J. Combination of Pantothenamides with Vanin Inhibitors as a Novel Antibiotic Strategy against Gram-Positive Bacteria Downloaded from. Antimicrob. Agents Chemother. 2013, 57, 4794-4800. [CrossRef] [PubMed]

160. Smith, C.M.; Cano, M.L.; Potyraj, J. The relationship between metabolic state and total CoA content of rat liver and heart. J. Nutr. 1978, 108, 854-862. [CrossRef]

161. Reibel, D.K.; Wyse, B.W.; Berkich, D.A.; Palko, W.M.; Neely, J.R.; Berkich, D.; Palko, W. Effects of diabetes and fasting on pantothenic acid metabolism in rats. Am. J. Physiol. 1981, 240, E597-E601. [CrossRef]

162. Leonardi, R.; Rock, C.O.; Jackowski, S. Pank1 deletion in leptin-deficient mice reduces hyperglycaemia and hyperinsulinaemia and modifies global metabolism without affecting insulin resistance. Diabetologia 2014, 57, 1466-1475. [CrossRef]

163. Tiwari, J.; Gupta, G.; De Jesus Andreoli Pinto, T.; Sharma, R.; Pabreja, K.; Matta, Y.; Arora, N.; Mishra, A.; Sharma, R.; Dua, K. Role of microRNAs (miRNAs) in the pathophysiology of Diabetes mellitus. Panminerva Med. 2018, 60, 25-28.

164. Vaishya, S.; Sarwade, R.D.; Seshadri, V. MicroRNA, proteins, and metabolites as novel biomarkers for prediabetes, diabetes, and related complications. Front. Endocrinol. 2018, 9, 180. [CrossRef]

165. Ashoori, M.R.; Rahmati-Yamchi, M.; Ostadrahimi, A.; Fekri Aval, S.; Zarghami, N. MicroRNAs and adipocytokines: Promising biomarkers for pharmacological targets in diabetes mellitus and its complications. Biomed. Pharmacother. 2017, 93, 1326-1336. [CrossRef]

166. Trajkovski, M.; Hausser, J.; Soutschek, J.; Bhat, B.; Akin, A.; Zavolan, M.; Heim, M.H.; Stoffel, M. MicroRNAs 103 and 107 regulate insulin sensitivity. Nature 2011, 474, 649-653. [CrossRef]

167. Zheng, K.; Chen, Z.; Feng, H.; Chen, Y.; Zhang, C.; Yu, J.; Luo, Y.; Zhao, L.; Jiang, X.; Shi, F. Sphingomyelin synthase 2 promotes an aggressive breast cancer phenotype by disrupting the homoeostasis of ceramide and sphingomyelin. Cell Death Dis. 2019, 10. [CrossRef]

168. Smith, M.; Flodman, P.L.; Gargus, J.J.; Simon, M.T.; Verrell, K.; Haas, R.; Reiner, G.E.; Naviaux, R.; Osann, K.; Spence, M.A.; et al. Mitochondrial and ion channel gene alterations in autism. Biochim. Biophys. Acta Bioenerg. 2012, 1817, 1796-1802. [CrossRef]

169. Hollis, F.; Kanellopoulos, A.K.; Bagni, C. Mitochondrial dysfunction in Autism Spectrum Disorder: Clinical features and perspectives. Curr. Opin. Neurobiol. 2017, 45, 178-187. [CrossRef]

170. Jackowski, S.; Leonardi, R. Deregulated coenzyme A, loss of metabolic flexibility and diabetes. Biochem. Soc. Trans. 2014, 42, 1118-1122. [CrossRef]

171. GWAS Catalog. Available online: https://www.ebi.ac.uk/gwas/search?query=CoAlevel (accessed on 3 August 2020).

172. Sabatti, C.; Service, S.K.; Hartikainen, A.L.; Pouta, A.; Ripatti, S.; Brodsky, J.; Jones, C.G.; Zaitlen, N.A.; Varilo, T.; Kaakinen, M.; et al. Genome-wide association analysis of metabolic traits in a birth cohort from a founder population. Nat. Genet. 2009, 41, 35-46. [CrossRef] [PubMed]

173. Lee, J.J.; Wedow, R.; Okbay, A.; Kong, E.; Maghzian, O.; Zacher, M.; Nguyen-Viet, T.A.; Bowers, P.; Sidorenko, J.; Karlsson Linnér, R.; et al. Gene discovery and polygenic prediction from a genome-wide association study of educational attainment in 1.1 million individuals. Nat. Genet. 2018, 50, 1112-1121. [CrossRef] [PubMed]

174. Coleman, J.R.I.; Peyrot, W.J.; Purves, K.L.; Davis, K.A.S.; Rayner, C.; Choi, S.W.; Hübel, C.; Gaspar, H.A.; Kan, C.; Van der Auwera, S.; et al. Genome-wide gene-environment analyses of major depressive disorder and reported lifetime traumatic experiences in UK Biobank. Mol. Psychiatry 2020, 25, 1430-1446. [CrossRef] [PubMed]

175. Comuzzie, A.G.; Cole, S.A.; Laston, S.L.; Voruganti, V.S.; Haack, K.; Gibbs, R.A.; Butte, N.F. Novel Genetic Loci Identified for the Pathophysiology of Childhood Obesity in the Hispanic Population. PLoS ONE 2012, 7 , e51954. [CrossRef] [PubMed] 
176. Hoffmann, T.J.; Choquet, H.; Yin, J.; Banda, Y.; Kvale, M.N.; Glymour, M.; Schaefer, C.; Risch, N.; Jorgenson, E. A large multiethnic genome-wide association study of adult body mass index identifies novel loci. Genetics 2018, 210, 499-515. [CrossRef]

177. Winkler, T.W.; Justice, A.E.; Graff, M.; Barata, L.; Feitosa, M.F.; Chu, S.; Czajkowski, J.; Esko, T.; Fall, T.; Kilpeläinen, T.O.; et al. The Influence of Age and Sex on Genetic Associations with Adult Body Size and Shape: A Large-Scale Genome-Wide Interaction Study. PLoS Genet. 2015, 11. [CrossRef]

178. Nagel, M.; Watanabe, K.; Stringer, S.; Posthuma, D.; Van Der Sluis, S. Item-level analyses reveal genetic heterogeneity in neuroticism. Nat. Commun. 2018, 9, 1-10. [CrossRef] [PubMed]

179. Evans, D.M.; Zhu, G.; Dy, V.; Heath, A.C.; Madden, P.A.F.; Kemp, J.P.; McMahon, G.; St. Pourcain, B.; Timpson, N.J.; Golding, J.; et al. Genome-wide association study identifies loci affecting blood copper, selenium and zinc. Hum. Mol. Genet. 2013, 26, 3998-4006. [CrossRef] [PubMed]

180. Cornelis, M.C.; Monda, K.L.; Yu, K.; Paynter, N.; Azzato, E.M.; Bennett, S.N.; Berndt, S.I.; Boerwinkle, E.; Chanock, S.; Chatterjee, N.; et al. Genome-wide meta-analysis identifies regions on 7p21 (AHR) and 15q24 (CYP1A2) as determinants of habitual caffeine consumption. PLoS Genet. 2011, 7, 1002033. [CrossRef] [PubMed]

181. Kennedy, O.J.; Pirastu, N.; Poole, R.; Fallowfield, J.A.; Hayes, P.C.; Grzeszkowiak, E.J.; Taal, M.W.; Wilson, J.F.; Parkes, J.; Roderick, P.J. Coffee Consumption and Kidney Function: A Mendelian Randomization Study. Am. J. Kidney Dis. 2020, 75, 753-761. [CrossRef]

182. Liu, C.; Kraja, A.T.; Smith, J.A.; Brody, J.A.; Franceschini, N.; Bis, J.C.; Rice, K.; Morrison, A.C.; Lu, Y.; Weiss, S.; et al. Meta-analysis identifies common and rare variants influencing blood pressure and overlapping with metabolic trait loci. Nat. Genet. 2016, 48, 1162-1170. [CrossRef]

183. Wu, Y.; Byrne, E.M.; Zheng, Z.; Kemper, K.E.; Yengo, L.; Mallett, A.J.; Yang, J.; Visscher, P.M.; Wray, N.R. Genome-wide association study of medication-use and associated disease in the UK Biobank. Nat. Commun. 2019, 10. [CrossRef]

184. Lai, J.; Wu, B.; Xuan, T.; Liu, Z.; Chen, J. Efficacy and tolerability of adding coenzyme A 400 U/d capsule to stable statin therapy for the treatment of patients with mixed dyslipidemia: An 8-week, multicenter, double-Blind, randomized, placebo-controlled study. Lipids Health Dis. 2014, 13. [CrossRef]

185. Lai, J.; Wu, B.; Xuan, T.; Xia, S.; Liu, Z.; Chen, J. Efficacy of Statin Monotherapy or in Combination With Coenzyme A Capsule in Patients With Metabolic Syndrome and Mixed Dyslipidemia. J. Clin. Med. Res. 2015, 7, 446-452. [CrossRef]

186. Donati, C.; Barbi, G.; Cairo, G.; Prati, G.F.; Degli Esposti, E. Pantethine improves the lipid abnormalities of chronic hemodialysis patients: Results of a multicenter clinical trial. Clin. Nephrol. 1986, 25, 70-74.

187. Rumberger, J.A.; Napolitano, J.; Azumano, I.; Kamiya, T.; Evans, M. Pantethine, a derivative of vitamin B5 used as a nutritional supplement, favorably alters low-density lipoprotein cholesterol metabolism in lowto moderate-cardiovascular risk North American subjects: A triple-blinded placebo and diet-controlled investig. Nutr. Res. 2011, 31, 608-615. [CrossRef]

188. Evans, M.; Rumberger, J.; Azumano, I.; Napolitano, J.; Citrolo, D.; Kamiya, T. Pantethine, a derivative of vitamin B5, favorably alters total, LDL and non-HDL cholesterol in low to moderate cardiovascular risk subjects eligible for statin therapy: A triple-blinded placebo and diet-controlled investigation. Vasc. Health Risk Manag. 2014, 10, 89. [CrossRef]

189. Gaddi, A.; Descovich, G.C.; Noseda, G.; Fragiacomo, C.; Colombo, L.; Craveri, A.; Montanari, G.; Sirtori, C.R. Controlled evaluation of pantethine, a natural hypolipidemic compound, in patients with different forms of hyperlipoproteinemia. Atherosclerosis 1984, 50, 73-83. [CrossRef]

190. Bertolini, S.; Donati, C.; Elicio, N.; Daga, A.; Cuzzolaro, S.; Marcenaro, A.; Saturnino, M.; Balestreri, R. Lipoprotein changes induced by pantethine in hyperlipoproteinemic patients: Adults and children. Int. J. Clin. Pharmacol. Ther. Toxicol. 1986, 24, 630-637. [PubMed]

191. Murai, A.; Miyahara, T.; Tanaka, T.; Sako, Y.; Nishimura, N.; Kameyama, M. The effects of pantethine on lipid and lipoprotein abnormalities in survivors of cerebral infarction. Artery 1985, 12, 234-243. [PubMed]

192. Chen, Y.Q.; Zhao, S.P.; Zhao, Y.H. Efficacy and tolerability of coenzyme A vs. pantethine for the treatment of patients with hyperlipidemia: A randomized, double-blind, multicenter study. J. Clin. Lipidol. 2015, 9, 692-697. [CrossRef]

193. Cighetti, G.; Del Puppo, M.; Paroni, R.; Galli, G.; Kienle, M.G. Effects of pantethine on cholesterol synthesis from mevalonate in isolated rat hepatocytes. Atherosclerosis 1986, 60, 67-77. [CrossRef] 
194. Cighetti, G.; Del Puppo, M.; Paroni, R.; Kienle, M.G. Modulation of HMG-CoA reductase activity by pantetheine/pantethine. Biochim. Biophys. Acta (BBA)/Lipids Lipid Metab. 1988, 963, 389-393. [CrossRef]

195. McCarty, M.F. Inhibition of acetyl-CoA carboxylase by cystamine may mediate the hypotriglyceridemic activity of pantethine. Med. Hypotheses 2001, 56, 314-317. [CrossRef]

196. Jones, M.L.; Tomaro-Duchesneau, C.; Martoni, C.J.; Prakash, S. Cholesterol lowering with bile salt hydrolase-active probiotic bacteria, mechanism of action, clinical evidence, and future direction for heart health applications. Expert Opin. Biol. Ther. 2013, 13, 631-642. [CrossRef]

197. Craig, J.A.; Snelll, E.E. The comparative activities of pantethine, pantothenic acid, and coenzyme A for various microorganisms. J. Bacteriol. 1951, 61, 283-291. [CrossRef]

198. Gyorgy, P.; Rose, C.S. Further observations on the metabolic requirements of Lactobacillus bifidus var. pennsylvanicus. J. Bacteriol. 1955, 69, 483-490. [CrossRef] [PubMed]

199. Sultanbawa, Y. Effects of bifidogenic factors on growth of bifidobacterium bifidum in cultured milk yoghurt. J. Natl. Sci. Found. Sri Lanka 2006, 34, 205. [CrossRef]

200. Hiramatsu, K.; Nozaki, H.; Arimori, S. Influence of pantethine on platelet volume, microviscosity, lipid composition and functions in diabetes mellitus with hyperlipidemia. Tokai J. Exp. Clin. Med. 1981, 6, 49-57. [PubMed]

201. Bittolo Bon, G.; Cazzolato, G.; Zago, S.; Avogaro, P. Effects of pantethine on in-vitro peroxidation of low density lipoproteins. Atherosclerosis 1985, 57, 99-106. [CrossRef]

Publisher's Note: MDPI stays neutral with regard to jurisdictional claims in published maps and institutional affiliations.

(C) 2020 by the authors. Licensee MDPI, Basel, Switzerland. This article is an open access article distributed under the terms and conditions of the Creative Commons Attribution (CC BY) license (http://creativecommons.org/licenses/by/4.0/). 